\title{
The Influence of Casting Conditions on the Microstructure of As-Cast U-10Mo Alloys: Characterization of the Casting Process Baseline
}
EA Nyberg
DM Paxton
W Joshi
DE Burkes
CA Lavender

December 2013

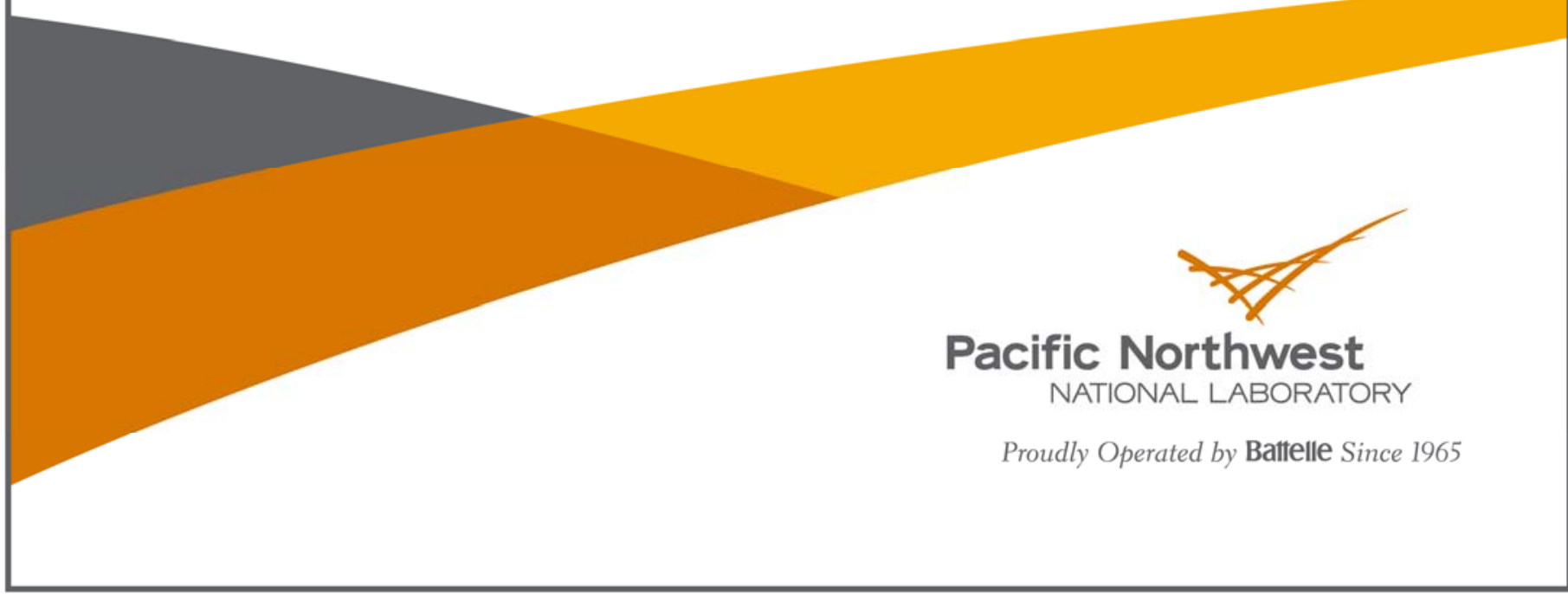




\title{
DISCLAIMER
}

This report was prepared as an account of work sponsored by an agency of the United States Government. Neither the United States Government nor any agency thereof, nor Battelle Memorial Institute, nor any of their employees, makes any warranty, express or implied, or assumes any legal liability or responsibility for the accuracy, completeness, or usefulness of any information, apparatus, product, or process disclosed, or represents that its use would not infringe privately owned rights. Reference herein to any specific commercial product, process, or service by trade name, trademark, manufacturer, or otherwise does not necessarily constitute or imply its endorsement, recommendation, or favoring by the United States Government or any agency thereof, or Battelle Memorial Institute. The views and opinions of authors expressed herein do not necessarily state or reflect those of the United States Government or any agency thereof.

\author{
PACIFIC NORTHWEST NATIONAL LABORATORY \\ operated by \\ BATTELLE \\ for the \\ UNITED STATES DEPARTMENT OF ENERGY \\ under Contract DE-AC05-76RL01830
}

Printed in the United States of America
Available to DOE and DOE contractors from the Office of Scientific and Technical Information, P.O. Box 62, Oak Ridge, TN 37831-0062; ph: (865) 576-8401 fax: $(865) 576-5728$
email: reports@adonis.osti.gov
Available to the public from the National Technical Information Service 5301 Shawnee Rd., Alexandria, VA 22312 ph: (800) 553-NTIS (6847) email: orders $a$ ntis.gov $<$ http://www.ntis.gov/about/form.aspx> Online ordering: http://www.ntis.gov




\title{
The Influence of Casting Conditions on the Microstructure of As-Cast U-10Mo Alloys: Characterization of the Casting Process Baseline
}

\author{
EA Nyberg \\ DM Paxton \\ VV Joshi \\ DE Burkes \\ CA Lavender
}

December 2013

Prepared for

the U.S. Department of Energy

under Contract DE-AC05-76RL01830

Pacific Northwest National Laboratory

Richland, Washington 99352 



\section{Executive Summary}

Sections of eight plate castings of uranium alloyed with $10 \mathrm{wt} \%$ molybdenum (U-10Mo) were sent from Y-12 to the Pacific Northwest National Laboratory (PNNL) for microstructural characterization. Casting variables included two different plate dimensions and two different post-casting heat-treatment durations. There was a duplicate of each casting condition which provided a measure of process variability. The degree of sample variation depended greatly on the thickness of the sample, where the sample came from within the casting, and whether the sample received a post-casting heat treatment.

In general, the grains were equiaxed and gross porosity and elemental segregation were not observed. However, a small fraction (i.e., less than 2 percent) of porosity less than 25 um micron in dimension was observed, primarily in discreet locations between dendrites. Similarly, no coarse carbides were observed (i.e., greater than $20 \mu \mathrm{m}$ ).

Inhomogeneity was observed on a microstructural scale in three forms: a) segregation of the Mo, b) grain size variation, and c) small carbide variation and distribution. The Mo appeared more segregated at the cooler, bottom ends of the castings and more uniformly distributed at the hotter, top ends of the castings. This inhomogeneity may be due to a combination of thermal gradients and the "coring" tendency of the U-Mo alloys. Regarding grain size, the tops of the castings, being hotter, had coarser grains than the bottoms of the castings. As the metal cooled more rapidly, the finer grains at the lower ends of the castings became apparent. For similar thermal management reasons, the thicker castings had larger grain size compared to the thinner castings. As for the carbide distribution and size, carbides were finer and less evenly distributed in the bottoms of the castings and predominately located at grain boundaries. Carbides were coarser and more evenly distributed on the tops of the castings and found both within the grain and at the boundaries. A dendritic microstructure was commonly observed in the thicker samples.

For heat-treated samples, a 4-hour in-mold hold did not homogenize the Mo in the thicker, 0.375-in. castings, but did appear to homogenize the Mo in the 0.200 -in. castings, likely due to the shorter diffusion

distance associated with the smaller dendrite size. Castings produced under similar conditions had different grain size profiles, suggesting some degree of process variation.

Additional homogenization studies are recommended to confirm the transformation kinetics. It should be verified that U-10Mo does not transform after homogenization. In similar inhomogeneous $\mathrm{U}-10 \mathrm{Mo}$ microstructures, transformation of the $\mathrm{U}-\mathrm{Mo}$ to alpha phase $\mathrm{U}$ and $\mathrm{U}_{2} \mathrm{Mo}$ has been observed; thus, care should be taken to ensure that the in-mold homogenization does not lead to a transformed structure. It is not clear if this transformation is a grain size or carbide effect. However, a minimum homogenization temperature of $1000^{\circ} \mathrm{C}$ may be required. A robust homogenization process must be established to prevent transformation.

Furthermore, due to the observed disparity in grain size from the top of a casting (i.e., large grain size) to the bottom (i.e., fine grain size) tighter control of the thermal gradient should be established. In addition, similar process runs have varying grain size and uniformity. Therefore, proper mold temperature gradient should be established through enhanced process controls and/or improved mold design. The gradient in top to bottom microstructure of the castings may be alleviated by homogenization; however, the time and possibly temperature to homogenize may be influenced by the gradient in the casting temperature. 



\section{Acknowledgments}

This work was funded by the U.S. Department of Energy and the National Nuclear Security Administration under the Global Threat Reduction Initiative Convert Program and performed at Pacific Northwest National Laboratory (PNNL) under contract DE-AC05-76RL01830. The authors would like to recognize the technical support in material handling and sample preparation by Ruby Ermi. In addition

the authors acknowledge Alan Schemer-Kohrn and Dan Edwards for their expertise in electron microscopy and elemental spectroscopy analysis. As indicated in the report, the experimental casting work was performed at the Y-12 Security Complex and shipped to PNNL for characterization. 



\section{Contents}

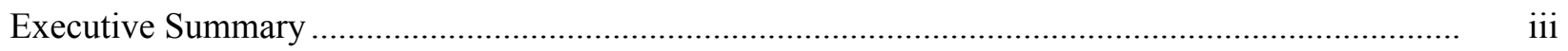

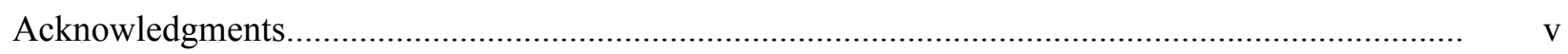

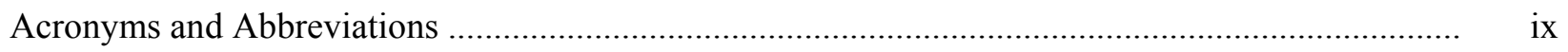

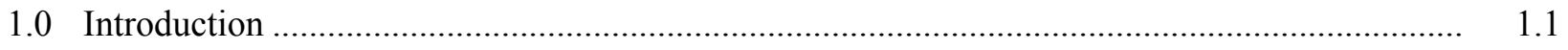

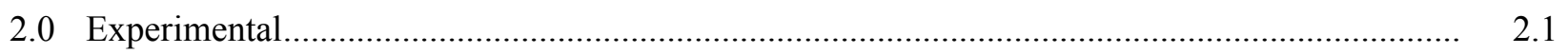

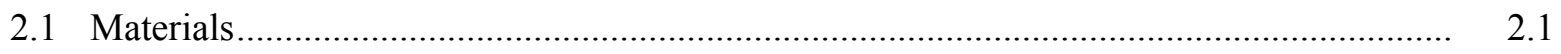

2.2 Scanning Electron and Optical Light Microscopy ...................................................... 2.3

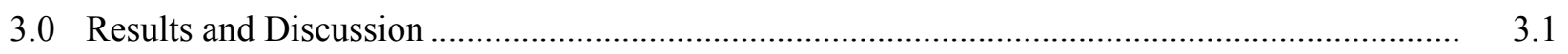

3.1 Microstructure of 0.200-in.-Thick Castings (No Hold and 4-Hour Hold) ......................... 3.1

$3.1 .1 \quad 0.200$-in.-Thick Castings (No Hold)................................................................ 3.1

3.1.2 0.200-in.-Thick Castings (4-Hour Hold) .......................................................... 3.4

3.1.3 0.200-in.-Thick Castings With and Without the 4-Hour Thermal Hold .................. 3.6

3.2 Microstructure of 0.375-in.-Thick Castings (No Hold and 4-Hour Hold) ......................... 3.7

3.2.1 0.375-in.-Thick Castings (No Hold) ............................................................... 3.7

3.2.2 0.375-in.-Thick Castings (4-Hour Hold) .......................................................... 3.10

3.2.3 0.375-in.-Thick Castings, With and Without the 4-Hour Hold............................... 3.11

3.3 Thickness and Thermal Hold Comparison (0.200 in. vs. 0.375-in. and No Hold vs. a

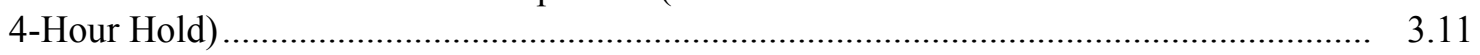

4.0 Potential Impact of Process Baseline Results ........................................................................

5.0 Conclusions and Recommendations ............................................................................. 5.1

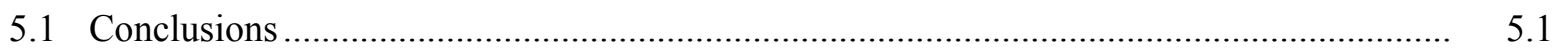

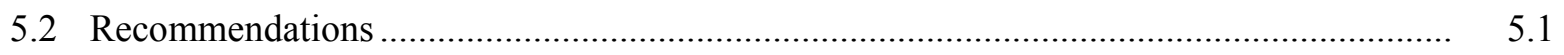

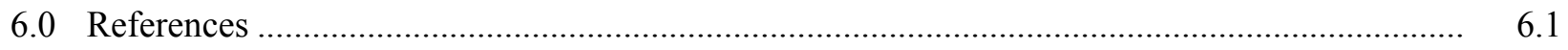

Appendix A - Table of Samples Received from Y-12 …........................................................ A.1 


\section{Figures}

2.1 Schematic of samples for the various casting thickness and heat treatments ........................... 2.1

2.2 Examples of cast size and cut plans for the 0.200- and 0.375-in.-thick samples ........................ 2.2

2.3 As-received U-10Mo castings from Y-12: YC-TVLD and YN-TW8W ................................. 2.2

3.1 SEM-BSE images of casting $3^{\text {rd }}$ Jude $0: 2$ of the top, middle, and bottom at $100 \mathrm{X}$ and $500 \mathrm{X} \ldots . . \quad 3.1$

3.2 SEM-BSE images of casting $5^{\text {th }}$ Matthew 0:2 of the top, middle, and bottom at 100X and $500 \mathrm{X}$

3.3 Optical image from the top section of the $3^{\text {rd }}$ Jude 0:2 sample with slight indication of dendritic structure still present.

3.4 EDS analysis of a region from the bottom section of the $5^{\text {th }}$ Matthew $0: 2$ sample..................... 3.3

3.5 SEM-BSE images of casting $4^{\text {th }}$ Jude $0: 2$ of the top, middle, and bottom at $100 \mathrm{X}$ and 500X..... 3.4

3.6 SEM-BSE images of casting YH-TW8W of the top, middle, and bottom at 100X and 500X.... 3.5

3.7 Optical image from the bottom section of $4^{\text {th }}$ Jude 0:2 sample with no indication of dendritic structure.

3.8 EDS analysis of a region from the bottom section of the $4^{\text {th }}$ Jude $0: 2$ sample............................ 3.6

3.10 SEM-BSE images of casting $1^{\text {st }}$ Matthew 3:8 of the top, middle, and bottom at 100X and $500 \mathrm{X}$

3.11 SEM-BSE images of casting DA-VJMX, $3^{\text {rd }}$ Judas 3:8 of the top, middle, and bottom at $100 \mathrm{X}$ and $500 \mathrm{X}$

3.12 EDS analysis of a region from the top section of the $1^{\text {st }}$ Matthew 3:8 sample .......................... 3.9

3.13 SEM-BSE images of casting $2^{\text {nd }}$ Judas $3: 8$ of the top, middle, and bottom at 100X and 500X ... 3.10

3.14 SEM-BES microstructures, from the top sections of each casting, showing variation in microstructure and carbide morphology as a function of thickness and thermal hold time.

3.15 Comparison of the microstructures from the bottom sections as a function of thickness and hold time.

3.17 3D micrograph of $2^{\text {nd }}$ Jude 3:8 sample.

4.2 Backscattered SEM image of the sample compression tested at $500^{\circ} \mathrm{C}$ at a strain rate of $6.5 \times 10^{-4} \mathrm{~s}^{-1}$

\section{Tables}

3.1 Microstructural data for the 0.200 -in.-thick castings with no hold

3.2 Microstructural data for the 0.200 -in.-thick castings with a 4-hour hold .................................. 3.5

3.3 Microstructural data for the 0.375 -in.-thick castings with no hold.......................................... 3.8

3.4 Microstructural data for the 0.375-in.-thick castings with a 4-hour hold ................................ 3.11

3.5 Summary of Microstructural Data for the 0.375 -in.-thick casting samples.............................. 3.11 


\section{Acronyms and Abbreviations}

$\begin{array}{ll}\text { HIP } & \text { hot isostatic processing } \\ \text { BSE } & \text { backscatter electron } \\ \text { EDS } & \text { energy-dispersive x-ray spectroscopy } \\ \text { HPRR } & \text { high-performance research reactors } \\ \text { LEU } & \text { low enriched uranium } \\ \text { Mo } & \text { molybdenum } \\ \text { PNNL } & \text { Pacific Northwest National Laboratory } \\ \text { SEM } & \text { scanning electron microscopy } \\ \text { U-10Mo } & \text { uranium alloyed with } 10 \mathrm{wt} \% \text { molybdenum }\end{array}$





\subsection{Introduction}

For several years, research to develop alternate fuels for high-performance research reactors (HPRRs) has been underway to replace high enriched uranium fuel with low enriched uranium (LEU) fuel (Burkes et al. 2009; Burkes et al. 2010a; Burkes et al. 2010b; Snelgrove et al. 1997). To achieve similar ${ }^{235} \mathrm{U}$ content with LEU, given reactor space constraints, a higher bulk density of fuel is needed, necessitating the use of monolithic metal alloy fuel. For this, an alloy that offers a good combination of irradiation performance, oxidation resistance, strength, and ductility is required for HPRR applications (Clark et al. 2006; Mcgeary 1955). Over several decades, various uranium alloys have been evaluated for favorable mechanical properties and for susceptibility to oxidation and corrosion. Uranium alloyed with $10 \mathrm{wt} \%$ molybdenum (U-10Mo) shows improvement in these characteristics compared to similar alloys (Burkes et al. 2009; Burkes et al. 2010a; Burkes et al. 2010b; Clark et al. 2006; Dombrowski 2012; Mcgeary 1955). Pacific Northwest National Laboratory (PNNL) is currently studying the effect of microstructure on the mechanical properties of U-10Mo. Similar research is being conducted by Joshi et al. (2013) and has been reported in Burkes et al. (2010a), Burkes et al. (2010b), Sinha et al. (2010a, b), and Sinha et al. (2009).

The fabrication process begins with U-10Mo alloys being vacuum induction melt cast into ingots for machining into coupons at the Y-12 National Security Complex (Y-12). Several different molds and feedstock materials were evaluated to cast the ingots, which are subsequently clad in zirconium and then with aluminum by hot isostatic processing and rolled to a final thickness of 150-500 microns.

To optimize future processing of the U-10Mo alloy, a comparative baseline of the casting process must be established. The results presented herein focus on the characterization of U-10Mo castings. Samples were produced at Y-12 under various conditions and delivered to PNNL. The castings, either 0.200 or 0.375 in. thick, were subjected to different post heat-treatment cycles. The impact of thermal heat treatment (with or without a 4-hour hold) and sample thickness ( 0.200 to 0.375 in.) on morphology and composition variation was examined. In addition, repeatability was evaluated by looking at similar castings produced under similar conditions. Finally, this study evaluated variation within a given casting and the potential impact of that variation on subsequent processing and fabrication steps. 



\subsection{Experimental}

\subsection{Materials}

A preliminary study at $\mathrm{Y}-12$ evaluated U-10Mo castings made with Mo feedstock as rod, powder, and strip. After several tests, the most consistent results were determined to be achieved when alloying with Mo in rod form. For the current study, Y-12 delivered eight castings to PNNL that used Mo rod as the alloy feedstock. Plate thicknesses of 0.200 and 0.375 in. were cast. The castings were poured at approximately $1400^{\circ} \mathrm{C}$ and were heat-treated either with a 4-hour thermal hold or with no hold. The hold temperature ranged from approximately 1100 to $1320^{\circ} \mathrm{C}$. All castings were furnace-cooled to an estimated $600^{\circ} \mathrm{C}$ and then air-cooled to room temperature. Figure 2.1 provides a test matrix with sample identifications and process variables for the eight castings, including Y-12 name (i.e., $3^{\text {rd }}$ Jude), Y-12 casting number (i.e., YN-TVLD) and PNNL metallography number (i.e., DUMO26). Specific details of the casting process are classified by Y-12 as Official Use Only/Export Controlled Information and are, therefore, not included in this report.

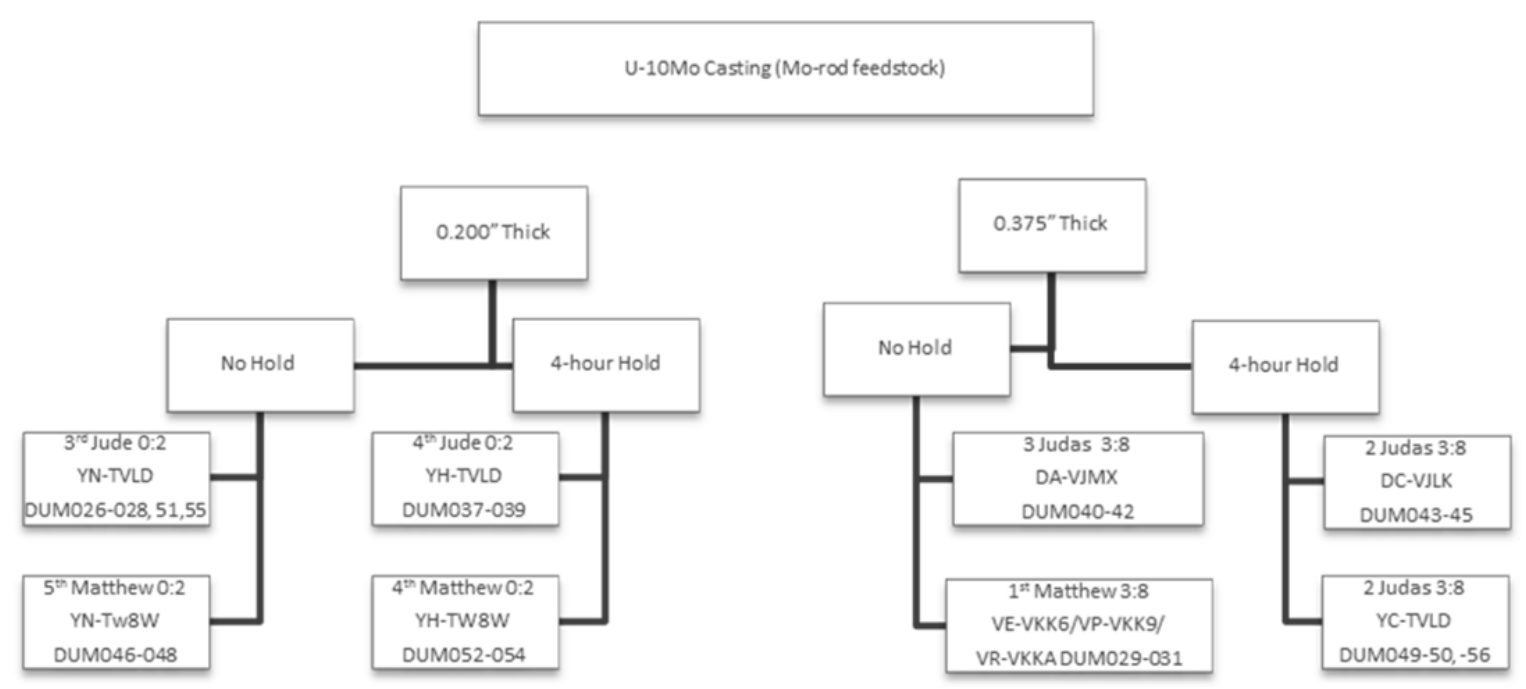

Figure 2.1. Schematic of samples for the various casting thickness and heat treatments

Samples were received as sections from the original cast plate. Specific locations from which samples were removed from the casting were identified by PNNL as top, middle, or bottom. It is important to note that these locations are relative for each casting and may not correlate to an exact location when comparing different casting thicknesses. For example, the "top" of the 0.200 -in.-thick casting may be 8.5 inches from its bottom end and the 0.375 -in. thick casting may have a top that is 5.3 inches from its bottom. Figure 2.2 is an example of the overall cast size and cut plans from Y-12 for two of the castings. Based on the information provided, the 0.200 -in.-thick castings had larger casting volume (13.6 to 15.0 in. $^{3}$ ) compared to the 0.375 -in.-thick castings $\left(9.9\right.$ to 14.0 in. $^{3}$ ). These differences relate to the overall height of the castings. The 0.200 -in.-thick castings were reported to be 8 in. wide and 8.5 to 9.4 in. tall. The 0.375 -in.-thick castings were 5 in. wide and 5.3 to 7.5 in. tall.

Figure 2.3 provides examples of as-received sections. Note that one cut section in the background is marked with a "TR" indicating a top right location/orientation of the casting. The other sample, 
YN-TW8W, was discovered to have been mismarked with the white arrow incorrectly pointing toward the bottom, rather than the top, as was originally intended.

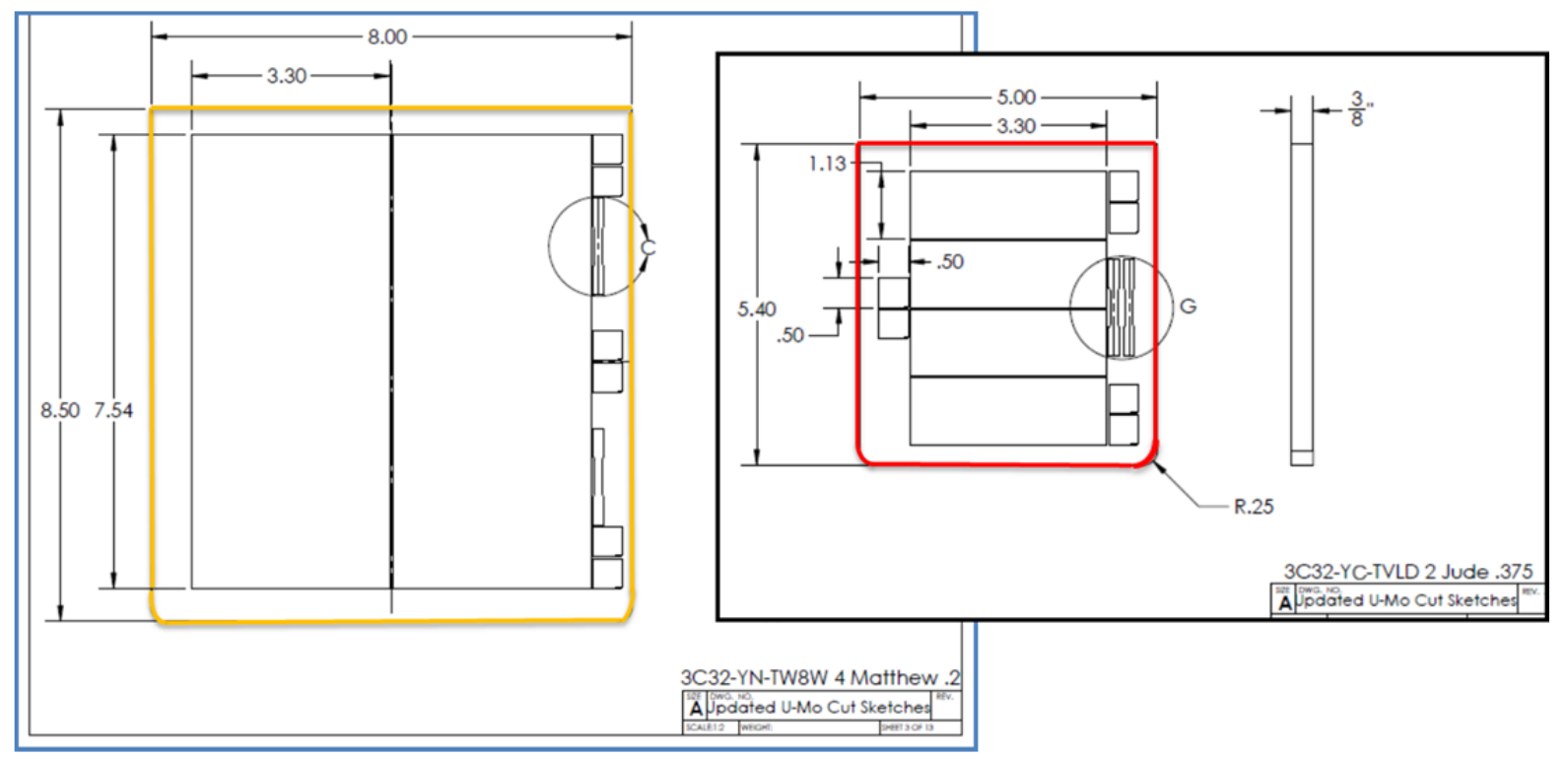

Figure 2.2. Examples of cast size and cut plans for the 0.200- and 0.375-in.-thick samples

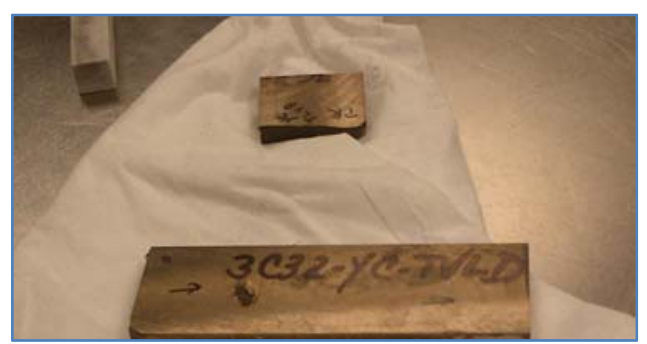

(a)

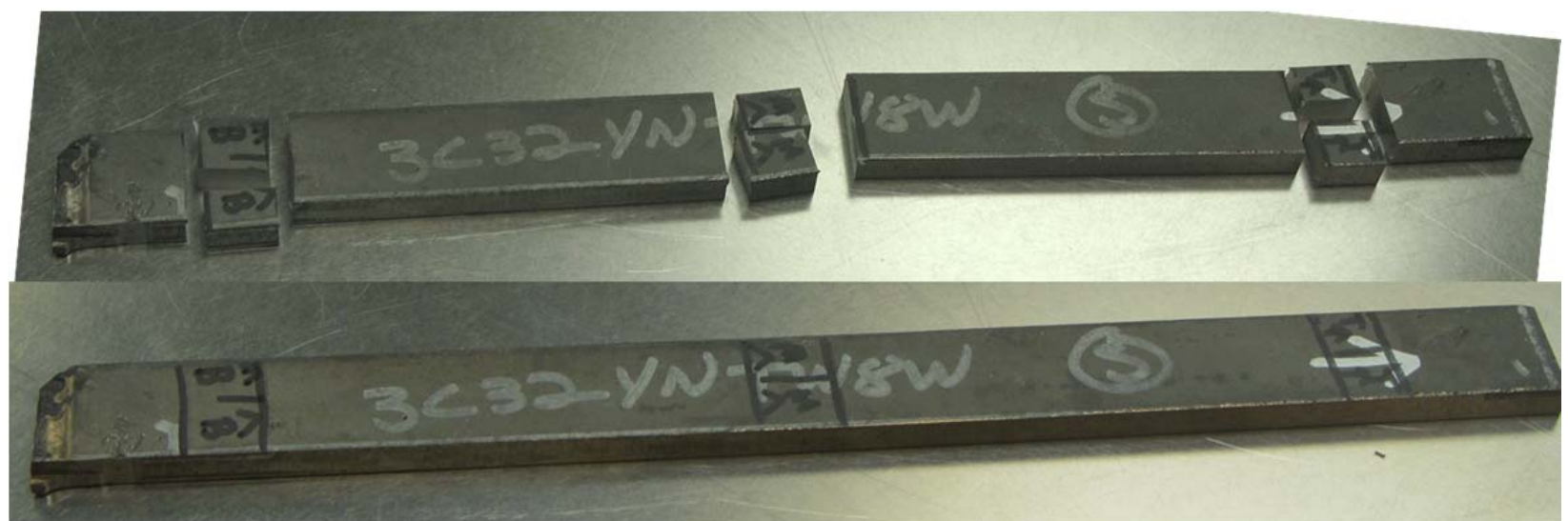

(b)

Figure 2.3. As-received U-10Mo castings from Y-12: (a) YC-TVLD and (b) YN-TW8W 


\subsection{Scanning Electron and Optical Light Microscopy}

For the cross sectional analysis, the cut sections were cold mounted in an epoxy resin. The mounted samples were successively polished with 600 -grit SiC polishing papers down to 6 and $1 \mu \mathrm{m}$ diamond slurries, followed by a final colloidal silica polish. Upon polishing, the samples were carbon coated for scanning electron microscopy (SEM) analysis. Grain size determination, second-phase particle examination, and chemical composition analysis were performed using a JEOL 7600F FEG-SEM equipped with an Oxford Instruments X-Max $80 \mathrm{~mm}^{2}$ SDD energy-dispersive x-ray spectroscopy (EDS). Semi-quantitative EDS analysis was performed to determine the variation in chemistry across the microstructure. EDS maps were then generated for a selected microstructure. Electron images were obtained using a proprietary JEOL low angle backscatter electron (BSE) detector, an in-lens secondary detector and a traditional Everhart-Thornley secondary electron detector. The Oxford AZtec software system was used for all EDS analytical analysis.

Optical light microscopic images were obtained using an Olympus BX61 optical microscope equipped with polarization filters. Digital images were captured using an Olympus UC50 camera and acquired using PAX-It digital imaging software. The microscope was equipped with objective lenses that could image the sample from 25 to 500X. Grain size analysis, quantitative image analysis, and carbide form and morphology were conducted on the SEM-BSE images at 100X and 500X magnification and were analyzed using ImageJ software. Grain size was measured manually by lineal analysis. Quantitative image analysis and carbide form was performed using ImageJ by adjusting the threshold of the area of interest and then processed using the automated analysis tool. The grain size measurements were determined by lineal analysis in low magnification mode. It should be noted that the carbide area fraction was measured in the BSE-SEM mode at low magnification. Variation in this data may be due to adjustment to the lighting threshold (brightness, gray-scale, and contrast). This qualitative adjustment can result in variation that will slightly enhance or obscure surface asperities, or artifacts, and thus may have contributed to the differences observed in the resulting values. The analysis on the shape/form (circularity/aspect ratio) of carbides was performed on high magnification images and has a higher level of quantitative accuracy. 



\subsection{Results and Discussion}

\subsection{Microstructure of 0.200-in.-Thick Castings (No Hold and 4-Hour Hold)}

Microstructure and composition were characterized for four 0.200-in.-thick castings. Two castings were examined in the as-cast condition and two were examined with a 4-hour hold following the casting.

\subsection{0-in.-Thick Castings (No Hold)}

Figure 3.1 and Figure 3.2 show the microstructures, as determined by SEM-BES, of the two as-cast samples (i.e., YN-TVLD $/ 3^{\text {rd }}$ Jude 0:2 and YN-TW8W $/ 5^{\text {th }}$ Matthew 0:2). These castings were $8 \times 9.1$ in. and $8 \times 8.5$ in., respectively. The images correspond to the top, middle, and bottom sections of the casting. Images in Figure 3.1a-c and Figure 3.2a-c, were taken at 100X and images in Figure 3.1d-f and Figure 3.2d-f were taken at 500X.

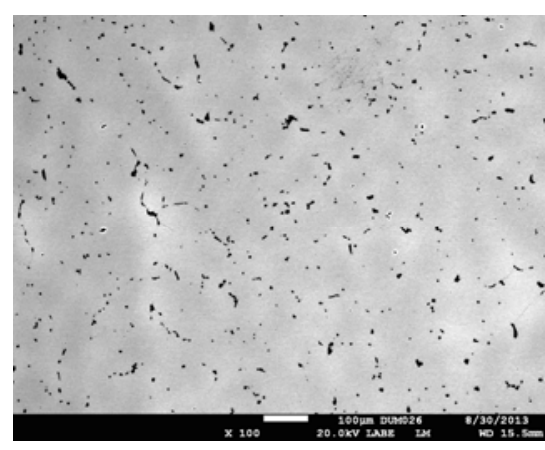

(a)

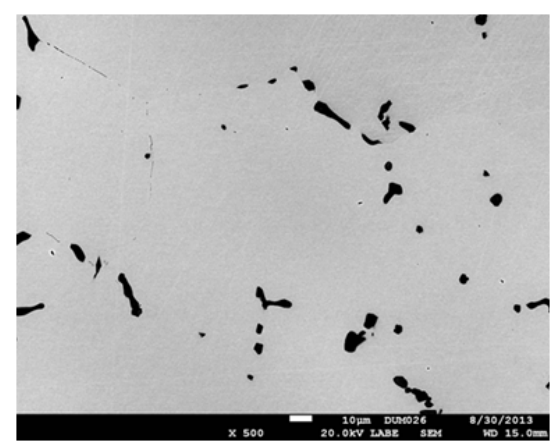

(d)

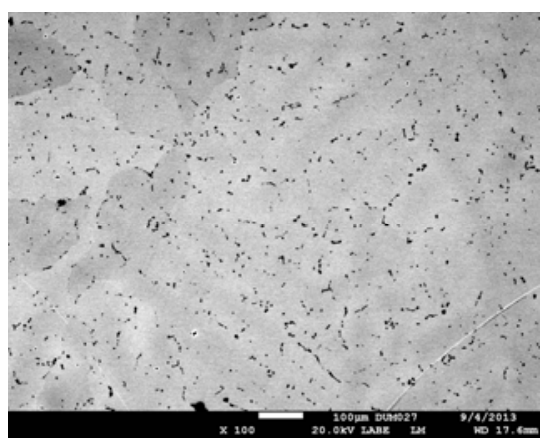

(b)

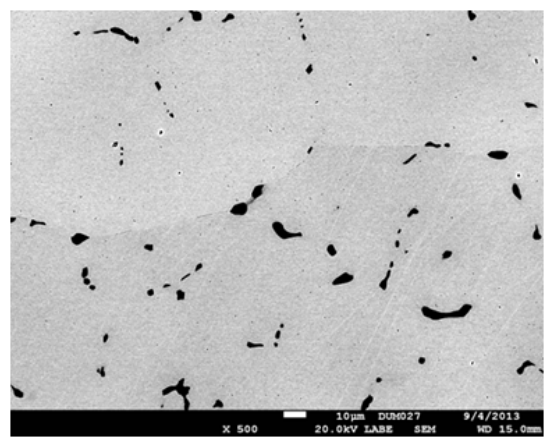

(e)

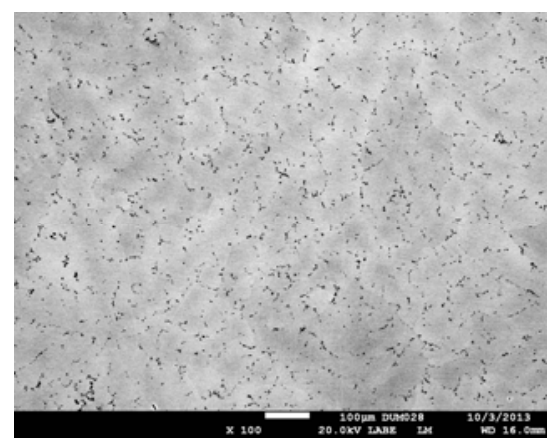

(c)

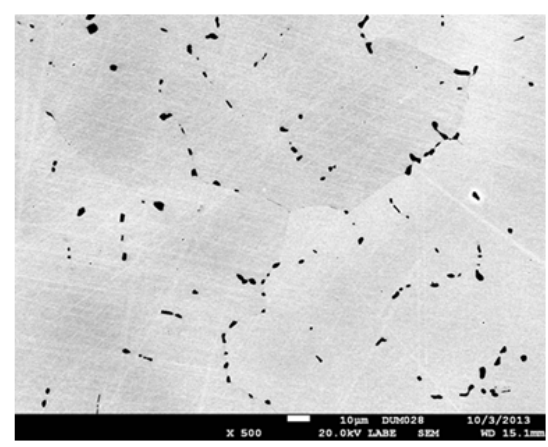

(f)

Figure 3.1. SEM-BSE images of casting $3^{\text {rd }}$ Jude 0:2 (0.200 in. thick, no hold) of the (a,d) top, (b,e) middle, and (c,f) bottom at (a-c) 100X and (d-f) 500X 


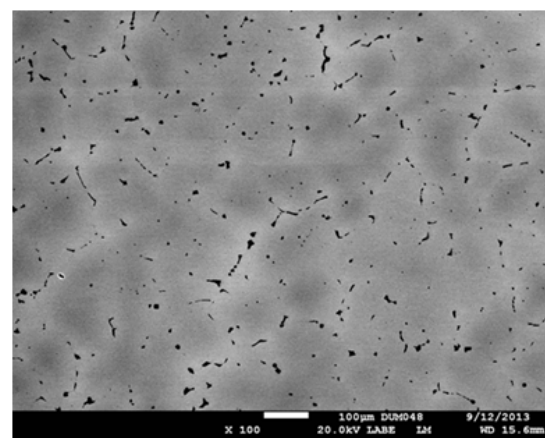

(a)

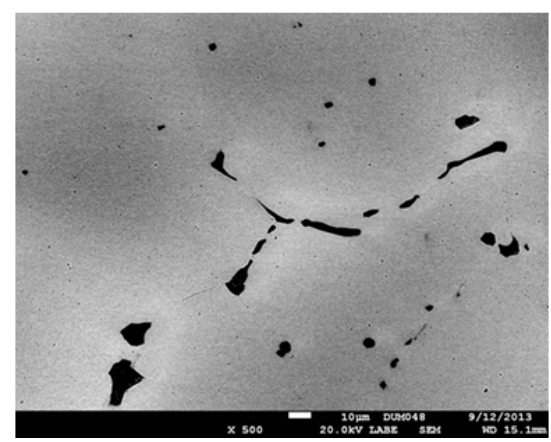

(d)

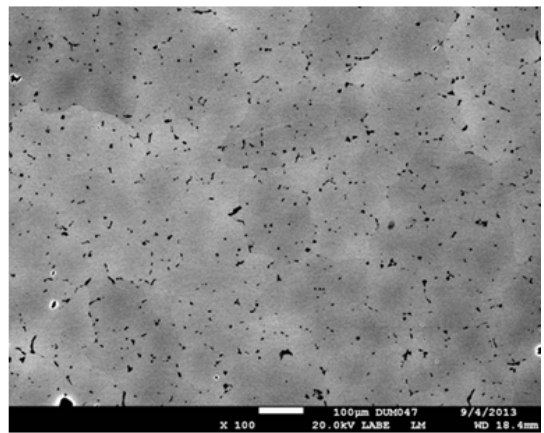

(b)

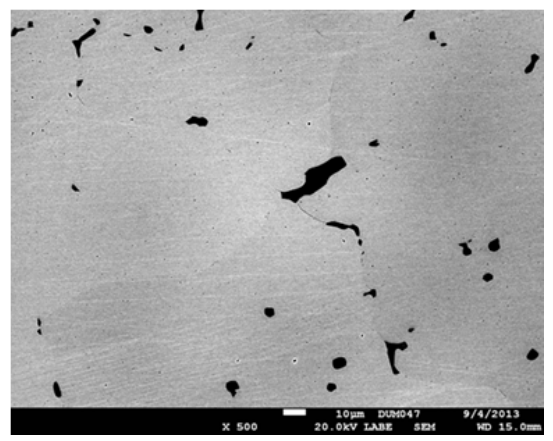

(e)

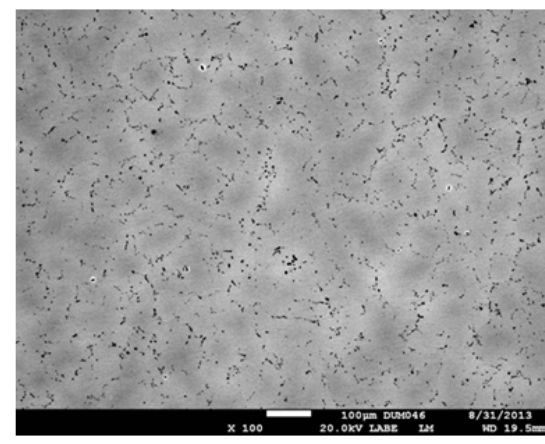

(c)

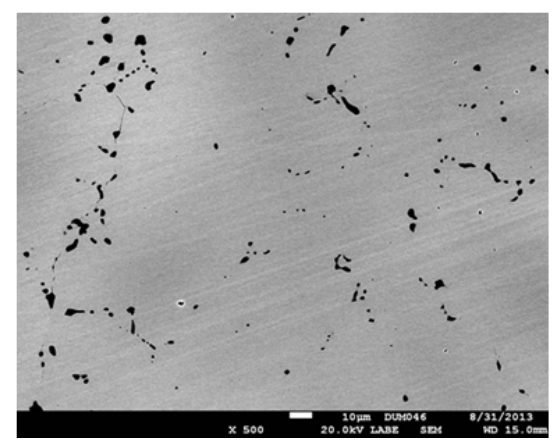

(f)

Figure 3.2. SEM-BSE images of casting $5^{\text {th }}$ Matthew 0:2 (0.200 in. thick, no hold) of the (a,d) top, (b,e) middle, and (c,f) bottom at (a-c) $100 \mathrm{X}$ and (d-f) $500 \mathrm{X}$

Table 3.1 summarizes the microstructural analytical data. The grain size decreases at the bottom of each casting, corresponding to cooler location and faster cooling rates. Specifically, the grain size varied from 70 to $36 \mu \mathrm{m}$ in sample $3^{\text {rd }}$ Jude $0: 2$ and from 85 to $60 \mu \mathrm{m}$ for sample $5^{\text {th }}$ Matthew 0:2. Microstructurally, these samples appear to vary in the extent to which they were homogenized, from partially homogenized (i.e., $3^{\text {rd }}$ Jude 0:2) to not at all (i.e., $5^{\text {th }}$ Matthew 0:2). The variation in Mo between the lean and rich regions was not detectable in these samples. Figure 3.3 shows an optical micrograph of the top region for $3^{\text {rd }}$ Jude 0:2. There is slight evidence of a dendritic structure appearing and isolated porosity observed at the dendrite interfaces, which were less than $25 \mu \mathrm{m}$ in size. As mentioned, although observed in the optical image, Mo segregation was not detected in the EDS measurements. Figure 3.4 shows an EDS map for the bottom region of $5^{\text {th }}$ Matthew 0:2. Mo segregation is evident and the variation in Mo concentration between the lean and rich regions was determined to be 1 to $2 \mathrm{wt} \%$. Uraniumcarbides (shown as the dark particles under the BSE-SEM image) were primarily located along the grain boundaries. In the case of $3^{\text {rd }}$ Jude 0:2, the carbides were elliptic with major axis lengths varying between 0.5 to $10 \mu \mathrm{m}$, The size of the carbides decreased from top to bottom, with minimal variation in area fraction. For the middle sections from the $3^{\text {rd }}$ and $4^{\text {th }}$ Jude 0:2 samples, the $A_{\mathrm{f}}$ and Circularity of the carbides varies slightly from the nominal values. As noted above in section 2.2 , measurement of the carbide quantity may be influenced by the lower magnification and slight variation in the lighting threshold used to make these measurements. The carbides were less than $5 \mu \mathrm{m}$ in length for the bottom samples. Similar to $3^{\text {rd }}$ Jude 0:2 samples, $5^{\text {th }}$ Matthew 0:2 samples displayed a trend in carbide size and form with carbides primarily located along the grain boundaries. 
Table 3.1. Microstructural data for the 0.200 -in.-thick castings with no hold

\begin{tabular}{|c|c|c|c|c|c|c|c|c|}
\hline Met ID & Baseline Char. ID & Name & Condition & $\begin{array}{c}\mathbf{A}_{\mathbf{f}} \text { of } \\
\text { Carbide }\end{array}$ & $\begin{array}{c}\text { Circularity } \\
\text { AR }\end{array}$ & $\begin{array}{c}\text { Grain } \\
\text { Size, } \\
\mu \mathrm{m}\end{array}$ & Homogenized & $\begin{array}{c}\% \\
\text { Dendrite }\end{array}$ \\
\hline DUM026 & YN-TVLD-Top & \multirow{3}{*}{$3^{\text {rd }}$ Jude $0: 2$} & \multirow{3}{*}{$\begin{array}{l}0.200 \text { in. no hold } \\
8 \times 9.1 \text { in. mold }\end{array}$} & 1.6 & 0.82 & 70.23 & \multirow{3}{*}{ Partially } & \multirow{3}{*}{$\begin{array}{c}\text { Not } \\
\text { Determined }\end{array}$} \\
\hline DUM027 & YN-TVLD-Middle & & & 2.3 & 0.95 & 55.91 & & \\
\hline DUM028 & YN-TVLD-Bottom & & & 1.6 & 0.82 & 36.25 & & \\
\hline DUM048 & YN-TW8W-Top & \multirow{3}{*}{$5^{\text {th }}$ Matthew $0: 2$} & \multirow{3}{*}{$\begin{array}{l}0.200 \text { in. no hold } \\
8 \times 8.5 \text { in. mold }\end{array}$} & 1.6 & 0.84 & 85.17 & $\mathrm{NO}$ & 34.16 \\
\hline DUM047 & YN-TW8W-Middle & & & 1.7 & 0.86 & 76.00 & YES & 0.00 \\
\hline DUM046 & YN-TW8W-Bottom & & & 1.7 & 0.89 & 60.66 & NO & 24.35 \\
\hline
\end{tabular}

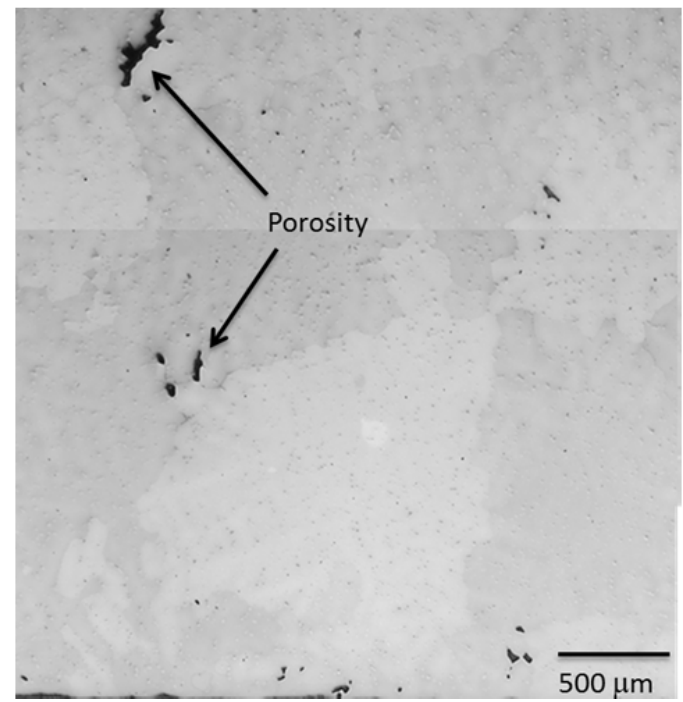

Figure 3.3. Optical image from the top section of the $3^{\text {rd }}$ Jude 0:2 sample with slight indication of dendritic structure still present
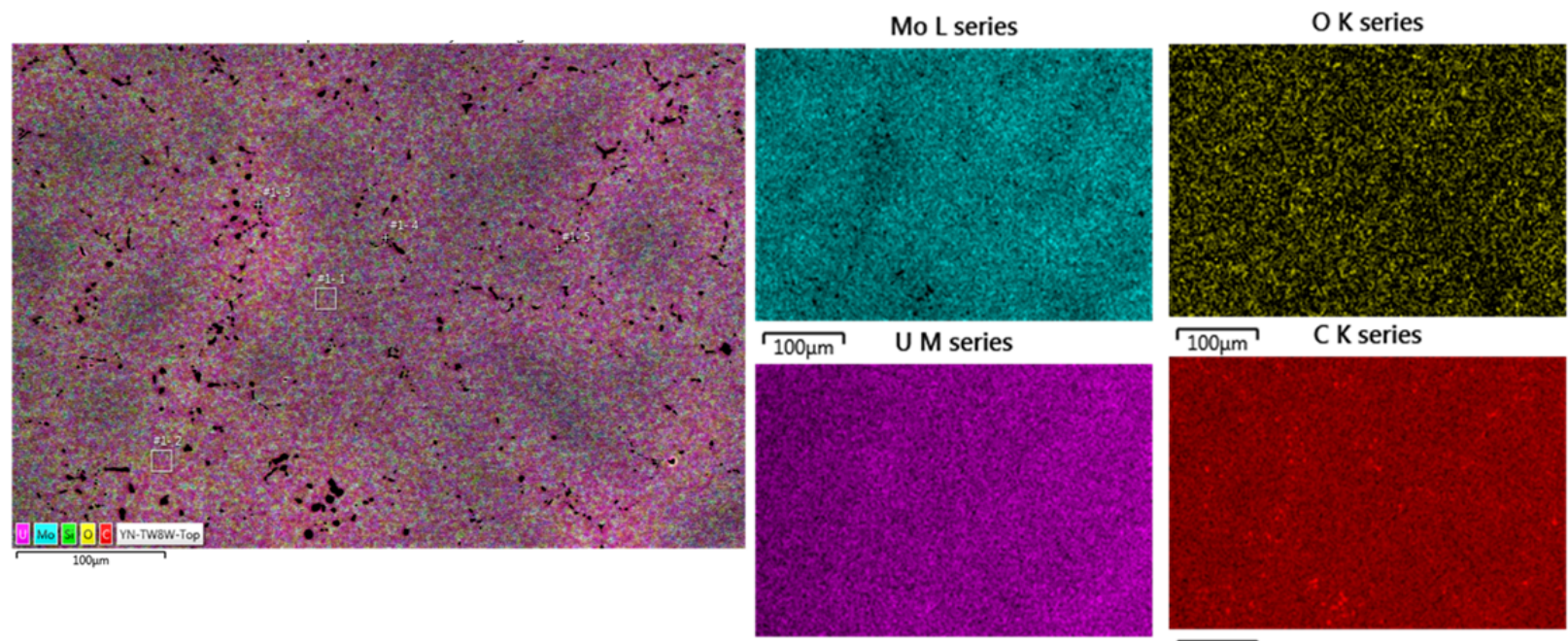

$\longdiv { 1 0 0 \mu \mathrm { m } }$

$\longdiv { 1 0 0 \mu \mathrm { m } }$

Figure 3.4. EDS analysis of a region from the bottom section of the $5^{\text {th }}$ Matthew 0:2 sample 


\subsection{0-in.-Thick Castings (4-Hour Hold)}

Micrographs from the two 0.200 -in.-thick castings that received a 4-hour thermal hold are shown in Figure 3.5 and Figure 3.6 (i.e., $4^{\text {th }}$ Jude $0: 2$ and $4^{\text {th }}$ Matthew). These castings were $8 \times 9.4$ in. and $8 \mathrm{x}$ 8.5 in., respectively. The images correspond to the top, middle, and bottom sections of the casting. The images on top (Figure $3.5 \mathrm{a}-\mathrm{c}$ ), at $100 \mathrm{X}$, show a $100 \mu \mathrm{m}$ scale and the lower images (Figure $3.5 \mathrm{~d}-\mathrm{f}$ ) at $500 \mathrm{X}$ have a $10 \mu \mathrm{m}$ scale.

Table 3.2 summarizes the microstructural analytical data. Again, despite the 4-hour hold, grain size decreases from $191 \mu \mathrm{m}$ (top region) to $54 \mu \mathrm{m}$ (bottom region) as measurements were made from the top toward the bottom of the castings. Figure 3.7 shows an optical micrograph of the top region for $4^{\text {th }}$ Jude $0: 2$. There is no evidence of a dendritic structure in this sample, suggesting homogenization has occurred. Figure 3.8 shows an EDS map for the bottom region of $4^{\text {th }}$ Jude $0: 2$, confirming fine, uniformly dispersed carbides with fairly uniform Mo distribution. Variation in the Mo concentration is not evident. At the top of the castings, the uranium-carbides in $4^{\text {th }}$ Jude 0:2 and $4^{\text {th }}$ Matthew 0:2 tended toward being more spherical, with diameters up to $10 \mu \mathrm{m}$; at the bottom of the castings the carbides were up to $5 \mu \mathrm{m}$ in diameter, with some retaining their needle shape. In the bottom section of $4^{\text {th }}$ Matthew $0: 2$, the area fraction of carbides increased. Carbides were located within and along the grain boundaries.

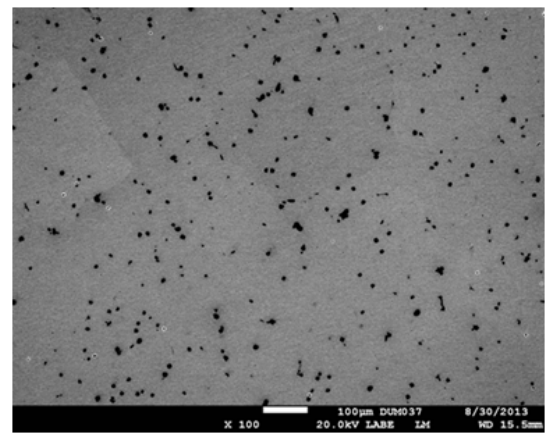

(a)

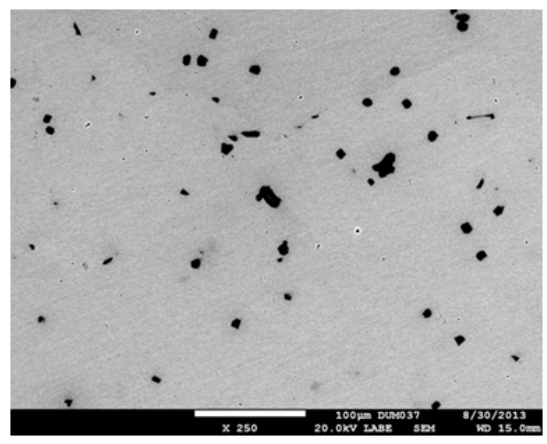

(d)

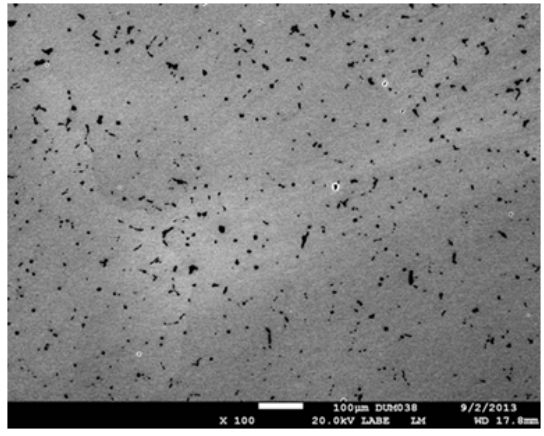

(b)

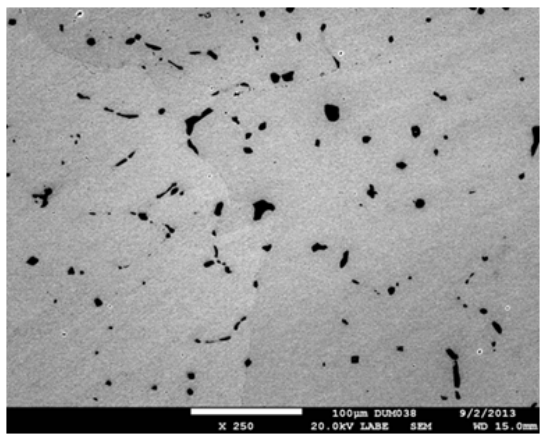

(e)

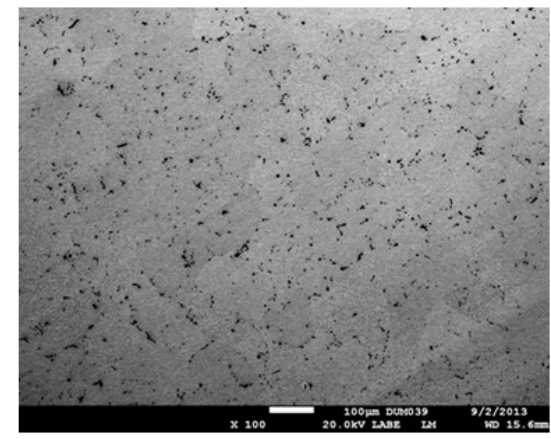

(c)

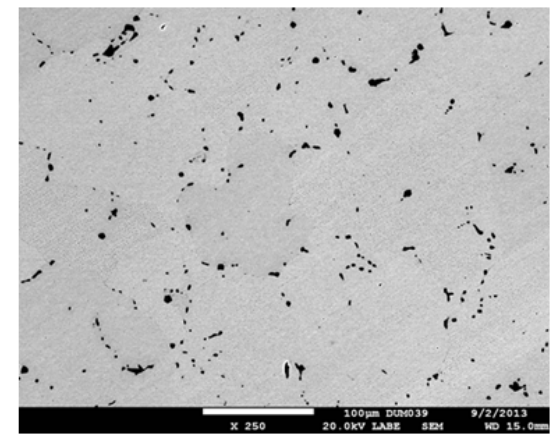

(f)

Figure 3.5. SEM-BSE images of casting $4^{\text {th }}$ Jude 0:2 (0.200 in. thick, 4-hour hold) of the (a,d) top, (b,e) middle, and (c,f) bottom at (a-c) $100 \mathrm{X}$ and (d-f) $500 \mathrm{X}$ 


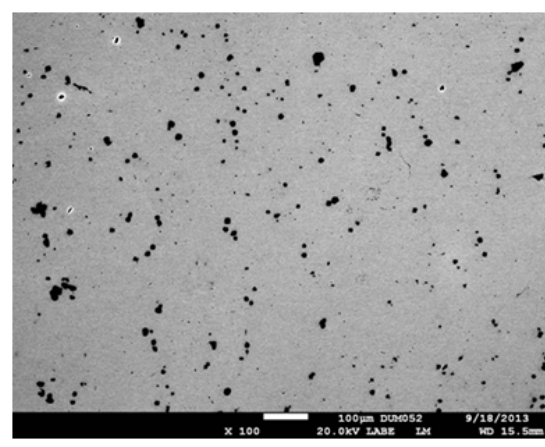

(a)

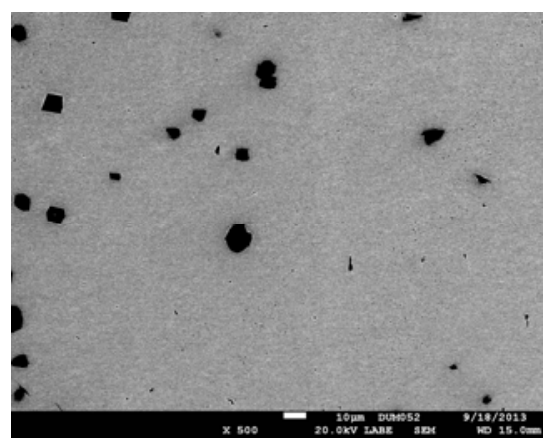

(d)

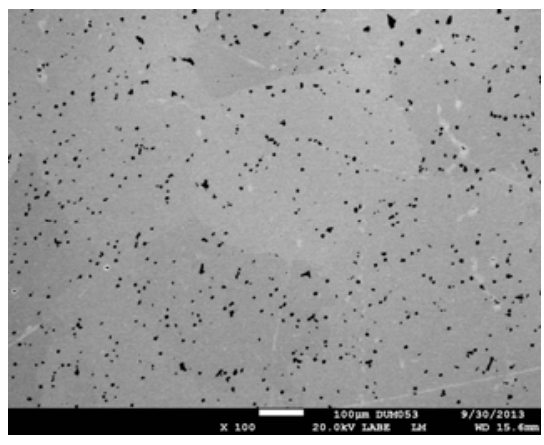

(b)

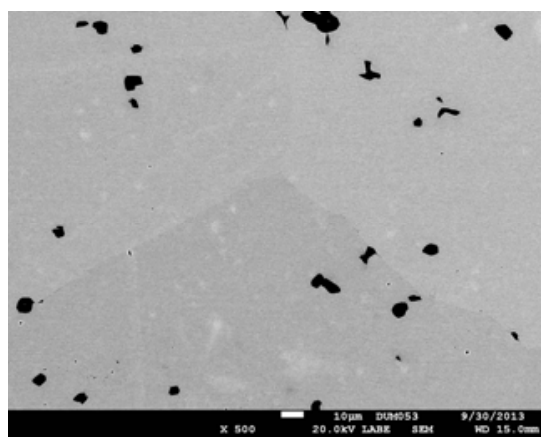

(e)

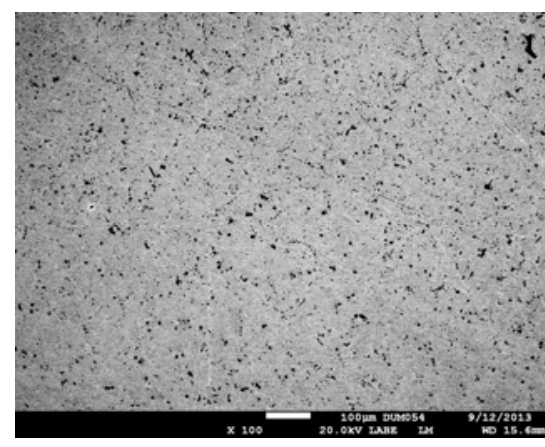

(c)

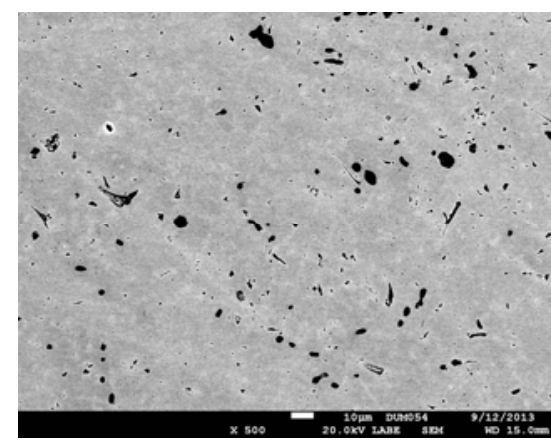

(f)

Figure 3.6. SEM-BSE images of casting YH-TW8W (0.200 in. thick, 4-hour hold) of the (a,d) top, (b,e) middle, and (c,f) bottom at (a-c) 100X and (d-f) 500X

Table 3.2. Microstructural data for the 0.200 -in.-thick castings with a 4-hour hold

\begin{tabular}{|c|c|c|c|c|c|c|c|c|}
\hline Met ID & Baseline Char. ID & Name & Condition & $\begin{array}{c}\mathbf{A}_{\mathrm{f}} \text { of } \\
\text { Carbide }\end{array}$ & $\begin{array}{c}\text { Circularity } \\
\text { AR } \\
\end{array}$ & $\begin{array}{c}\text { Grain } \\
\text { Size } \mu \mathrm{m}\end{array}$ & Homogenized & $\begin{array}{c}\% \\
\text { Dendrite } \\
\end{array}$ \\
\hline DUM037 & YH-TVLD-Top & \multirow{3}{*}{$4^{\text {th }}$ Jude $0: 2$} & \multirow{3}{*}{$\begin{array}{c}0.200 \text { in., } 4 \text {-hour } \\
\text { hold } \\
5 \times 5.3 \text { in. mold }\end{array}$} & 1.7 & 0.91 & 191.25 & YES & 0.00 \\
\hline DUM038 & YH-TVLD-Middle & & & 2.3 & 0.94 & 112.50 & YES & 0.00 \\
\hline DUM039 & YH-TVLD-Bottom & & & 2.0 & 0.97 & 54.22 & YES & 0.00 \\
\hline DUM052 & YH-TW8W Top & \multirow{3}{*}{$\begin{array}{c}4^{\text {th }} \text { Matthew } \\
0: 2\end{array}$} & \multirow{3}{*}{$\begin{array}{c}0.200 \text { in., } 4 \text {-hour } \\
\text { hold } \\
8 \times 9.4 \text { in. mold }\end{array}$} & 2.0 & 0.94 & \multirow{3}{*}{$\begin{array}{c}>150 \\
\mu \mathrm{m}\end{array}$} & YES & 0.00 \\
\hline DUM053 & YH-TW8W Middle & & & 1.7 & 0.88 & & YES & 0.00 \\
\hline DUM054 & YH-TW8W Bottom & & & 4.2 & 0.93 & & YES & 0.00 \\
\hline
\end{tabular}

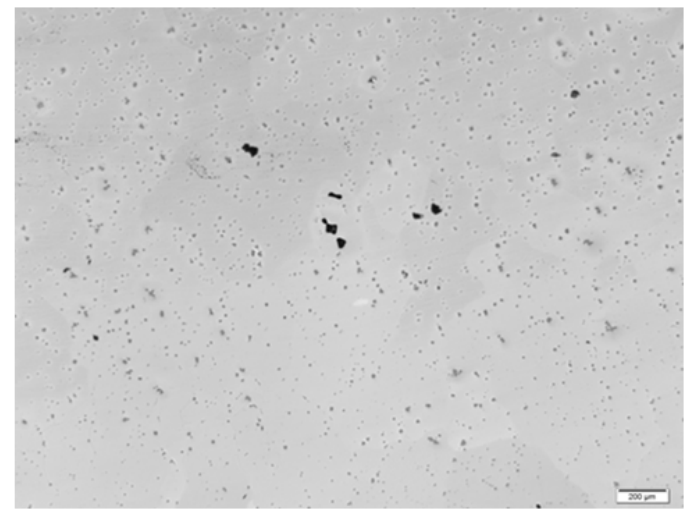

Figure 3.7. Optical image from the bottom section of $4^{\text {th }}$ Jude $0: 2$ sample with no indication of dendritic structure. 


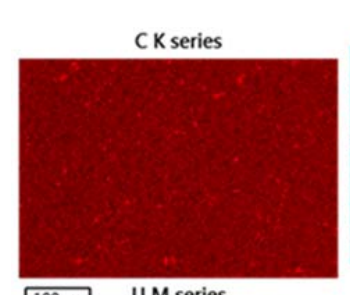

$\overparen{100 \mu \mathrm{m}} \mathrm{U}$ M series
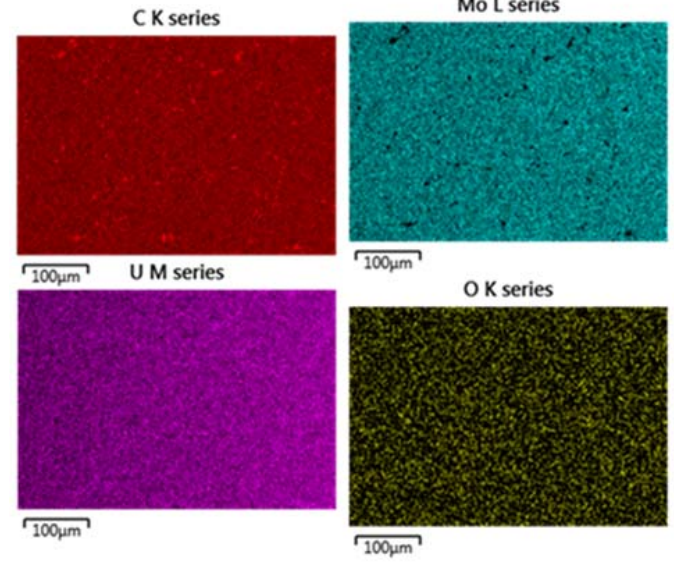

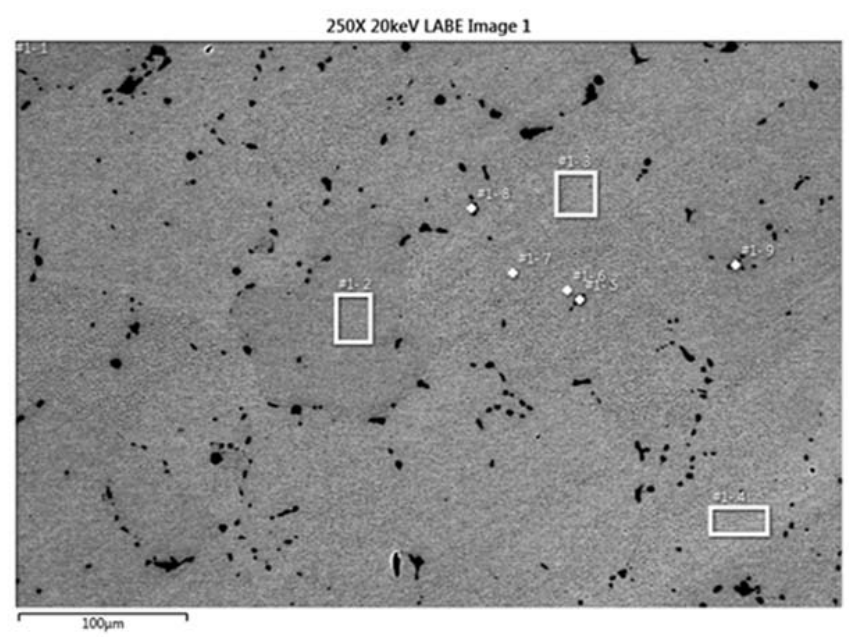

Figure 3.8. EDS analysis of a region from the bottom section of the $4^{\text {th }}$ Jude 0:2 sample.

\subsection{0-in.-Thick Castings With and Without the 4-Hour Thermal Hold}

Results of the 0.200 -in.-thick castings indicated that, for all castings, grain size varied from top to bottom, decreasing in grain size toward the cooler, bottom regions of the castings. The carbides in castings with a 4-hour hold were larger and more spherical than those in castings with no hold. Indications that homogenization was beginning to occur were observed in castings with no thermal hold.

Figure 3.9 presents a comparison between the top and bottom regions of the castings with and without the 4-hour hold The increase in homogeneity particularly evident in the coarsening of the carbide particles in both the top (Figure 3.9c) and bottom (Figure 3.9d) micrographs for the as-cast plus 4-hour hold sample ( $4^{\text {th }}$ Matthew 0:2). There is no dendritic structure evident in the SEM images. The grain size increases from bottom to top in all cases and all as-cast samples exhibit smaller grain size than those subjected to a 4-hour hold. The variation in grain size between samples with similar processing parameters (e.g., $3^{\text {rd }}$ Jude 0:2 and $5^{\text {th }}$ Matthew 0:2) can be attributed to the surface area to volume ratio of the castings, which directly correlates to the solidification rate. In addition, other factors (e.g., effective mold filling and die conditions) directly affect the cooling/solidification rate and, hence, the grain size. 


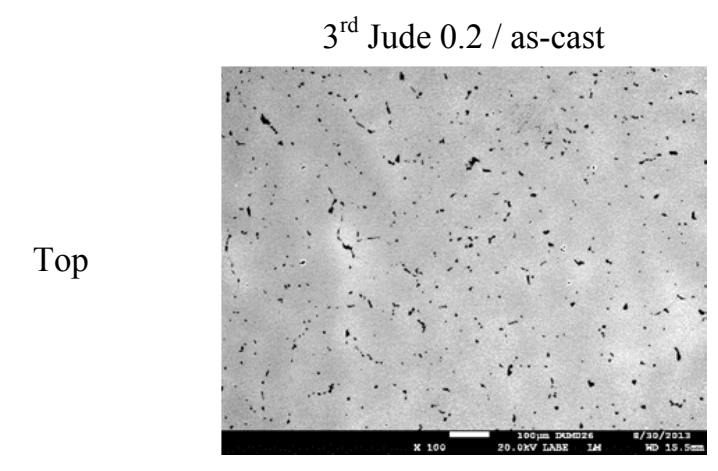

(a)

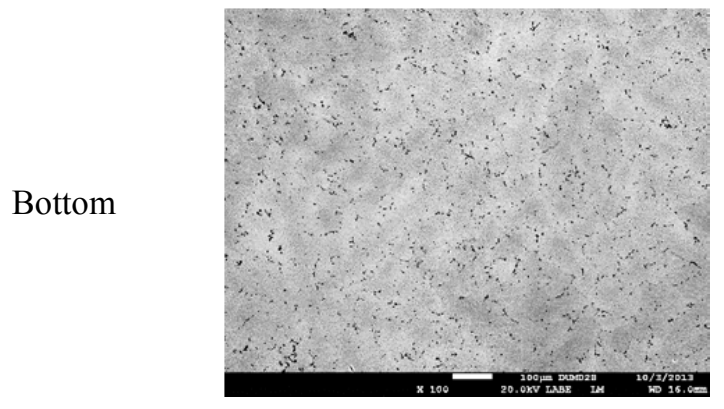

(c)

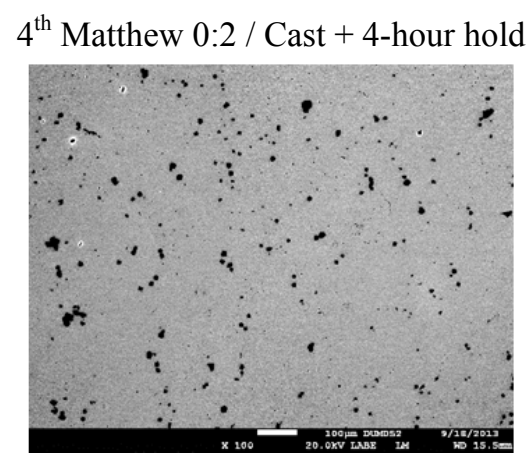

(b)

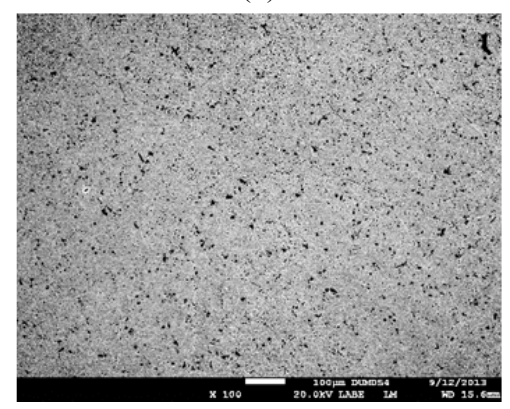

(d)

Figure 3.9. SEM-BSE images of 0.200-in.-thick castings, comparing microstructure with and without a 4-hour hold. (a) and (c) are the top and bottom, respectively, of the as-cast sample (i.e., $3^{\text {rd }}$ Jude 0.2 ) and (b) and (d) are the top and bottom, respectively, of the as-cast plus 4-hour hold sample (i.e., $4^{\text {th }}$ Matthew 0:2).

\subsection{Microstructure of 0.375-in.-Thick Castings (No Hold and 4-Hour Hold)}

Microstructure and composition were characterized for four 0.375 -in.-thick castings. Similar to the thinner castings, two castings were examined in the as-cast condition and two were examined with a 4-hour hold following the casting.

\subsection{5-in.-Thick Castings (No Hold)}

The data for the two samples with no hold, $1^{\text {st }}$ Matthew 3:8 and $3^{\text {rd }}$ Judas 3:8, are given below in Table 3.3. Recall that $1^{\text {st }}$ Matthew was a 5- x 5.3-in. casting and $3^{\text {rd }}$ Judas was a 5- $x$ 7.4-in. casting. Although the trends are similar (i.e., grain size decreases away from the top of the casting), the grain size for $1^{\text {st }}$ Matthew was significantly smaller than that for $3^{\text {rd }}$ Judas. As previously discussed, grain size is directly proportional to surface area to volume ratio, effective mold filling, and die temperatures at the time of casting, etc. However, the unavailability of the processing parameters makes it hard to correlate the same. Further, the variation in grain size is greater for the longer casting (i.e., $3^{\text {rd }}$ Judas, which decreased from 125 to $66 \mu \mathrm{m}$ ) compared to the shorter casting (i.e., $1^{\text {st }}$ Matthew, which decreased from 50 to $35 \mu \mathrm{m})$. Note that these samples were pre-cut from the original casting and sent to PNNL; thus, the $1^{\text {st }}$ Matthew 3:8 samples do not have the ( $5^{\text {th }}$ Matthew 0:2) YN-TW8W baseline characterization sample identification. None of the thicker, no thermal hold samples were homogenized, which is evident by a defined dendritic microstructure (30 to 50 percent) with Mo segregation. Dendrites were approximately 
75 to $100 \mu \mathrm{m}$ in width. Carbides appeared to have a high aspect ratio and were present in the Mo-lean regions.

Table 3.3. Microstructural data for the 0.375 -in.-thick castings with no hold.

\begin{tabular}{|c|c|c|c|c|c|c|c|c|}
\hline Met ID & $\begin{array}{c}\text { Baseline Char. } \\
\text { ID }\end{array}$ & Name & Condition & $\begin{array}{c}\mathbf{A}_{\mathbf{f}} \text { of } \\
\text { Carbide }\end{array}$ & $\begin{array}{c}\text { Circularity } \\
\text { AR }\end{array}$ & $\begin{array}{c}\text { Grain } \\
\text { Size, } \\
\mu \mathrm{m}\end{array}$ & Homogenized & $\begin{array}{c}\% \\
\text { dendrite }\end{array}$ \\
\hline DUM029 & VEVKK6-T1 & \multirow{3}{*}{$\begin{array}{c}1^{\text {st }} \text { Matthew } \\
3: 8\end{array}$} & \multirow{3}{*}{$\begin{array}{l}0.375 \text { in. no hold } \\
5 \times 5.3 \text { in. mold }\end{array}$} & 1.7 & 0.95 & 50.13 & $\mathrm{NO}$ & 32.55 \\
\hline DUM030 & VPVKK9-M1 & & & 2.2 & 0.77 & 44.64 & $\mathrm{NO}$ & 39.54 \\
\hline DUM031 & VRVKKA-B1 & & & 1.9 & 0.80 & 35.19 & $\mathrm{NO}$ & 45.17 \\
\hline DUM040 & DAVJMX-T1 & \multirow{3}{*}{$3^{\text {rd }}$ Judas 3:8 } & \multirow{3}{*}{$\begin{array}{l}0.375 \text { in. no hold } \\
5 \times 7.4 \text { in. mold }\end{array}$} & 1.1 & 0.82 & 125.00 & $\mathrm{NO}$ & 31.21 \\
\hline DUM041 & DAVJMX-M1 & & & 1.2 & 0.86 & 79.45 & $\mathrm{NO}$ & 39.40 \\
\hline DUM042 & DAVJMX-B1 & & & 1.3 & 0.88 & 66.00 & $\mathrm{NO}$ & 51.73 \\
\hline
\end{tabular}

Figure 3.10 and Figure 3.11 show the microstructure of the two samples in the as-cast condition (i.e., $1^{\text {st }}$ Matthew 3:8 and $3^{\text {rd }}$ Judas 3:8). These castings were $5 \times 5.3$ in. and $5 \times 7.4$ in., respectively. The images correspond to the top, middle, and bottom sections of the casting. The images on top (a-c) show a $100 \mu \mathrm{m}$ scale and the lower images (d-f) show a $10 \mu \mathrm{m}$ scale. The dendritic structure is evident throughout, particularly at the lower magnifications. Figure 3.12 summarizes the EDS analysis conducted on the top section of the $1^{\text {st }}$ Matthew 3:8 sample. From the EDS maps, the Mo-rich and Mo-lean regions are evident. It was determined by the EDS analysis that in the top section, of the $1^{\text {st }}$ Matthew 3:8 sample Mo concentration varied 2 to $3 \mathrm{wt} \%$.

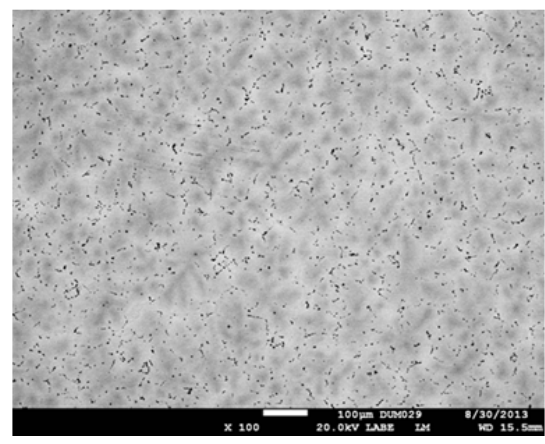

(a)

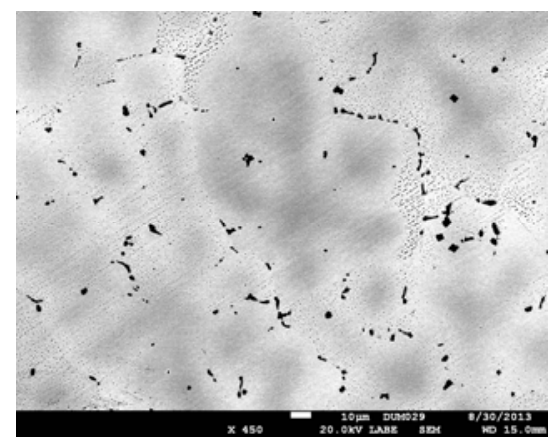

(d)

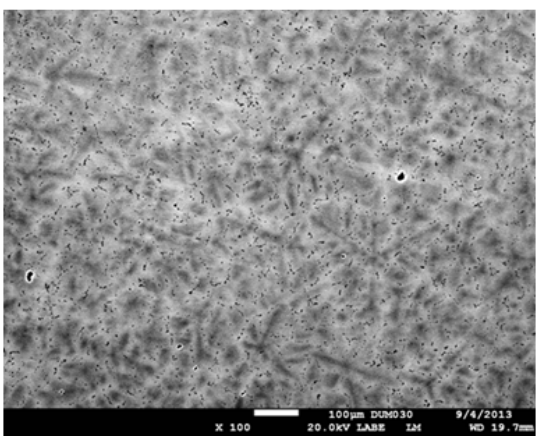

(b)

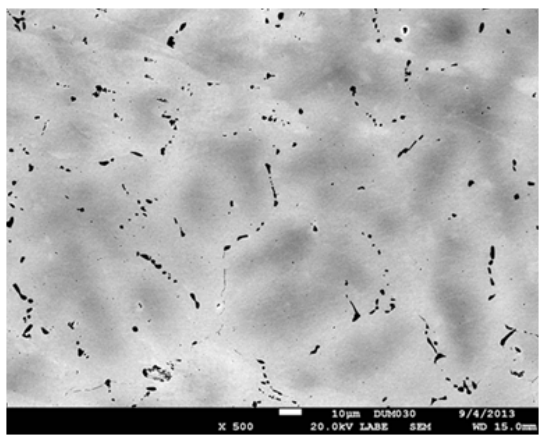

(e)

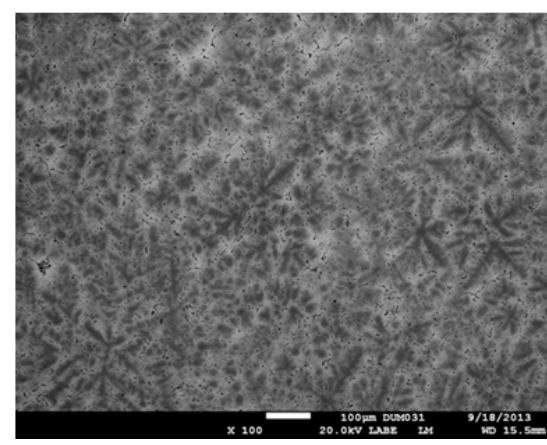

(c)

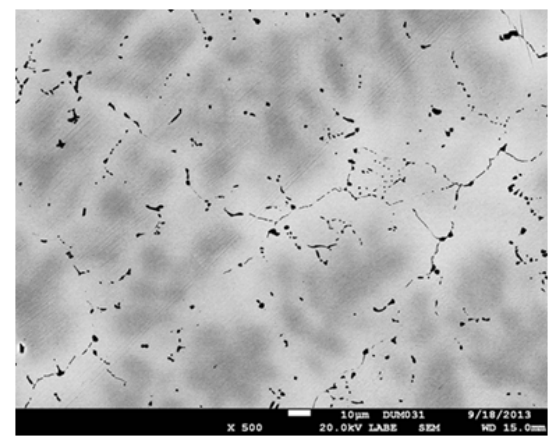

(f)

Figure 3.10. SEM-BSE images of casting $1^{\text {st }}$ Matthew 3:8 (0.375 in. thick, no hold) of the (a,d) top, (b,e) middle, and (c,f) bottom at (a-c) $100 \mathrm{X}$ and (d-f) $500 \mathrm{X}$ 


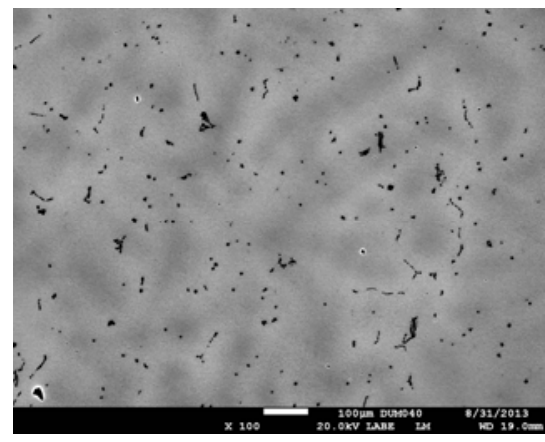

(a)

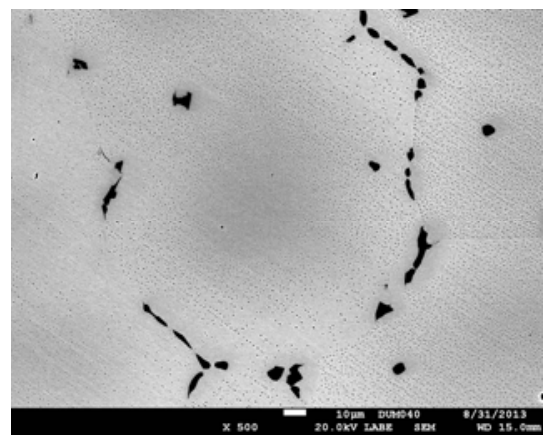

(d)

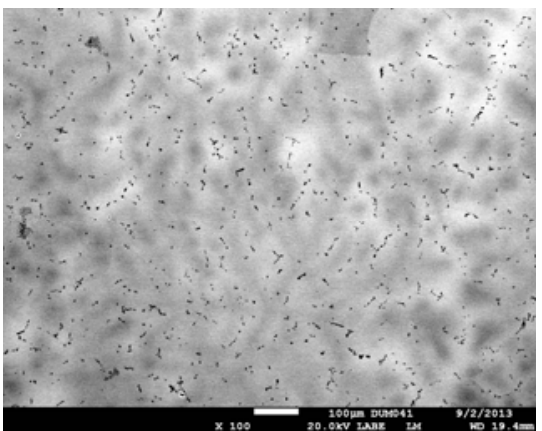

(b)

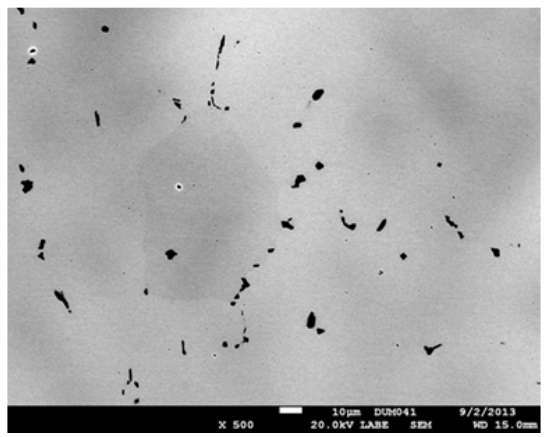

(e)

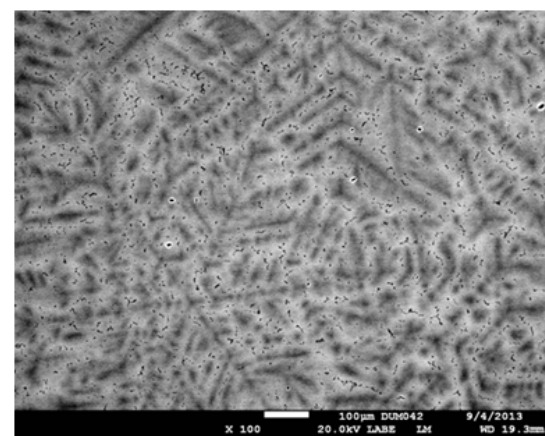

(c)

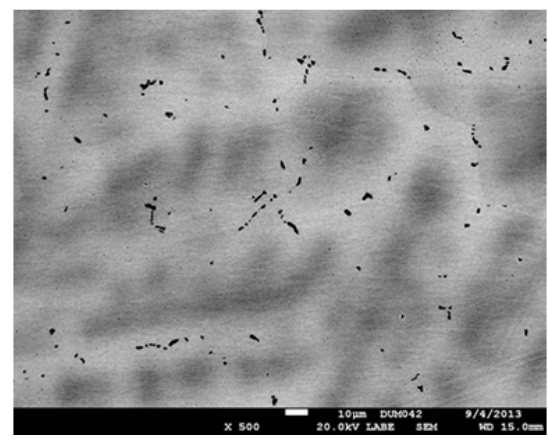

(f)

Figure 3.11. SEM-BSE images of casting DA-VJMX, $3^{\text {rd } J u d a s ~} 3: 8(0.375$ in. thick, no hold $)$ of the (a,d) top, $(\mathrm{b}, \mathrm{e})$ middle, and $(\mathrm{c}, \mathrm{f})$ bottom at $(\mathrm{a}-\mathrm{c}) 100 \mathrm{X}$ and $(\mathrm{d}-\mathrm{f}) 500 \mathrm{X}$

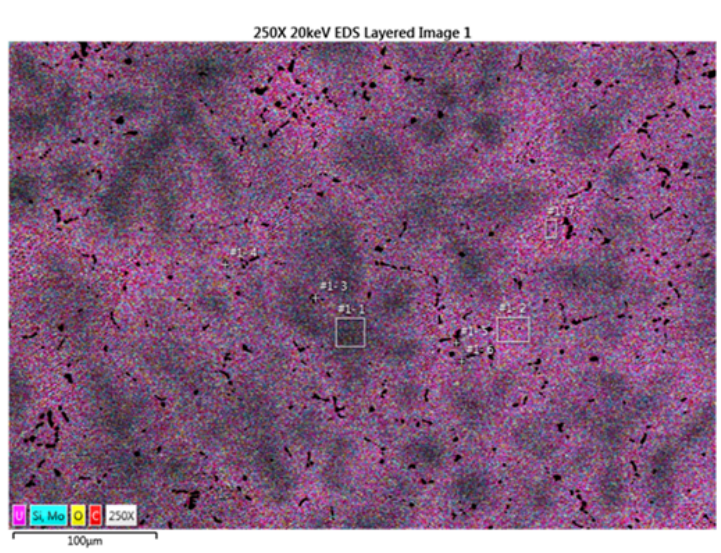

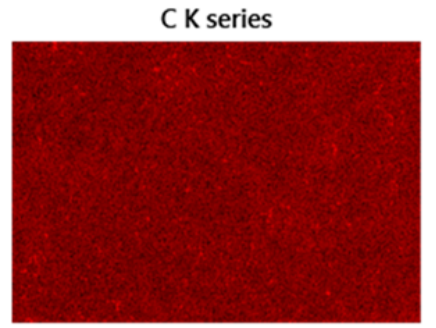

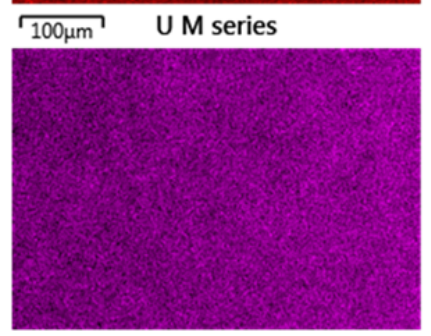

$\sqrt{100 \mu \mathrm{m}}$
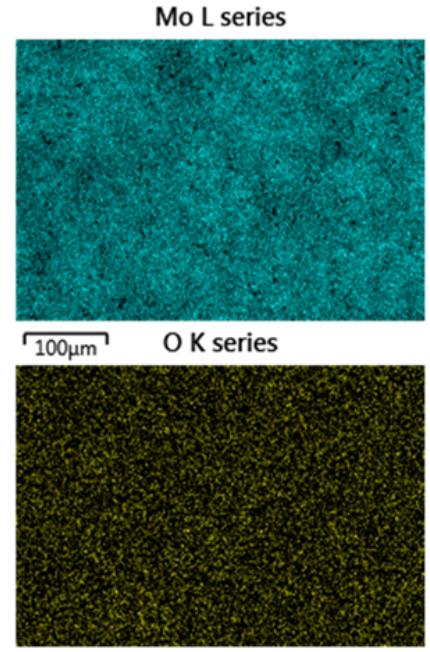

$\longdiv { 1 0 0 \mu \mathrm { m } }$

Figure 3.12. EDS analysis of a region from the top section of the $1^{\text {st }}$ Matthew $3: 8$ sample 


\subsection{5-in.-Thick Castings (4-Hour Hold)}

Figure 3.13 shows representative micrographs from one of the 0.375 -in.-thick samples receiving a 4-hour thermal hold (i.e., $2^{\text {nd }}$ Judas 3:8). The dimensions of this casting were $5 \times 7.5 \mathrm{in}$. According to the processing schematic provided, the second casting (i.e., $2^{\text {nd }}$ Jude $3: 8$ ) was $5 \times 5.4$ in. and only one sample was provided for examination, it was indicated as being from the middle section of the casting. The images in Figure 3.13 correspond to the top, middle, and bottom sections of the $2^{\text {nd }}$ Judas $3: 8$ casting. The micrographs on top (a-c) were taken at $100 \mathrm{X}$ and show a $100 \mu \mathrm{m}$ scale while the images on bottom (d-f) were taken at 500X and have a $10 \mu \mathrm{m}$ scale.

Table 3.4 shows the microstructural analytical data for $2^{\text {nd }}$ Jude $3: 8$ and $2^{\text {nd }}$ Judas 3:8. As before, the grain size decreased (from 159 to $74 \mu \mathrm{m}$ ) corresponding to measurements taken from the top and bottom of the casting. This casting was not homogenized, evident throughout by the strong dendritic structure and non-uniform Mo segregation. The carbides in this case also had a high aspect ratio with major axis length anywhere between 2 to $5 \mu \mathrm{m}$. Carbides were primarily located along grain boundaries.

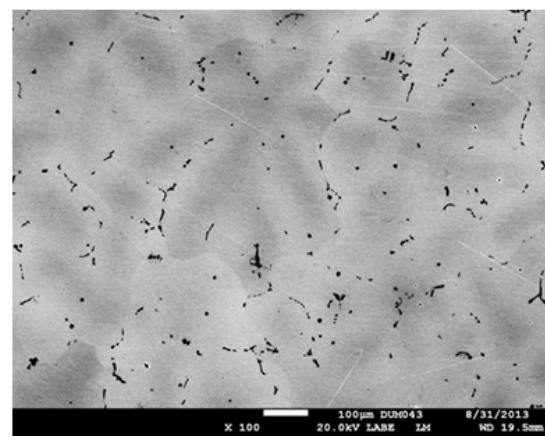

(a)

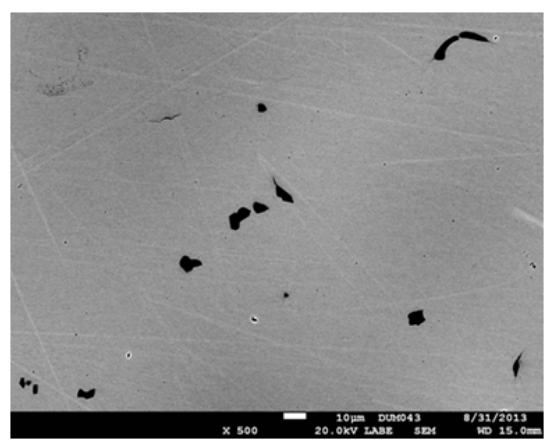

(d)

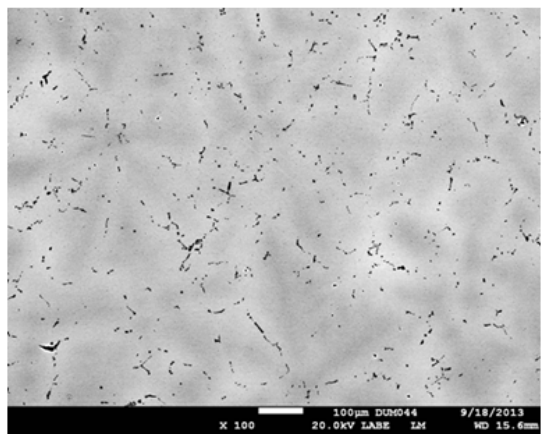

(b)

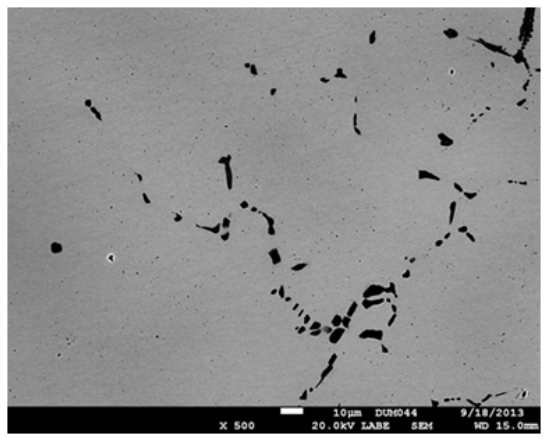

(e)

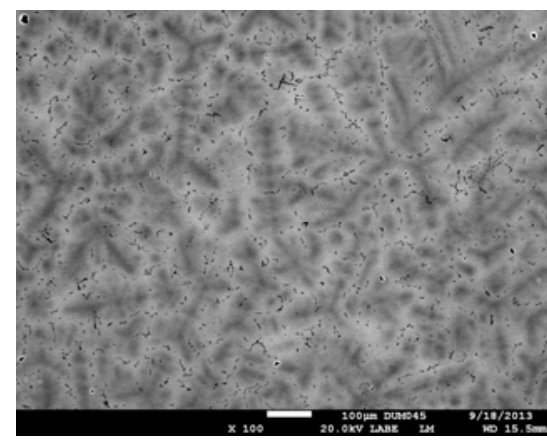

(c)

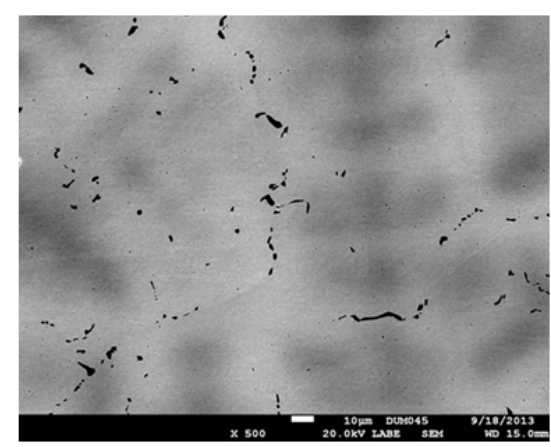

(f)

Figure 3.13. SEM-BSE images of casting $2^{\text {nd }}$ Judas 3:8 (0.375 in. thick, 4-hour hold) of the (a,d) top, $(\mathrm{b}, \mathrm{e})$ middle, and $(\mathrm{c}, \mathrm{f})$ bottom at $(\mathrm{a}-\mathrm{c}) 100 \mathrm{X}$ and $(\mathrm{d}-\mathrm{f}) 500 \mathrm{X}$ 
Table 3.4. Microstructural data for the 0.375 -in.-thick castings with a 4-hour hold

\begin{tabular}{|c|c|c|c|c|c|c|c|c|}
\hline Met ID & $\begin{array}{c}\text { Baseline Char. } \\
\text { ID }\end{array}$ & Name & Condition & $A_{f}$ of Carbide & $\begin{array}{c}\text { Circularity } \\
\text { AR }\end{array}$ & $\begin{array}{l}\text { Grain } \\
\text { Size, } \\
\mu \mathrm{m}\end{array}$ & Homogenized & $\begin{array}{c}\% \\
\text { dendrite }\end{array}$ \\
\hline DUM049 & YCTVLD-M1 & $2^{\text {nd }}$ Jude $3: 8$ & $\begin{array}{c}0.375 \text { in. } 4 \text {-hour } \\
\text { hold } \\
5 \times 5.4 \text { in. mold }\end{array}$ & 1.9 & 0.86 & 55 & No & 44.32 \\
\hline DUM043 & DC-VJLK-T1 & \multirow{3}{*}{$2^{\text {nd }}$ Judas $3: 8$} & \multirow{3}{*}{$\begin{array}{c}0.375 \text { in. 4-hour } \\
\text { hold } \\
5 \times 7.5 \text { in. mold }\end{array}$} & 1.2 & 0.79 & 159.17 & $\mathrm{NO}$ & 23.74 \\
\hline DUM044 & DC-VJLK-M1 & & & 1.2 & 0.86 & 111.11 & $\mathrm{NO}$ & 32.15 \\
\hline DUM045 & DC-VJLK-B1 & & & 1.3 & 0.88 & 74.18 & $\mathrm{NO}$ & 50.65 \\
\hline
\end{tabular}

\subsection{5-in.-Thick Castings, With and Without the 4-Hour Hold.}

Table 3.5 summarizes the individual sample data presented above for the 0.375 -in.-thick castings (i.e., the no-hold and 4-hour hold samples). For all samples, including those from the top of the castings with a 4-hour hold, there was little evidence that the castings were homogenized and all showed classic dendritic structure and Mo segregation. Samples with similar casting conditions showed significant variation in grain size, indicating process variability. For example, top-region samples with no hold had grain sizes of 50 and $125 \mu \mathrm{m}$. Similarly, middle-region samples with 4-hour hold, had grain sizes of 111 and $55 \mu \mathrm{m}$.

Table 3.5. Summary of Microstructural Data for the 0.375-in.-thick casting samples.

\begin{tabular}{|c|c|c|c|c|c|c|c|c|}
\hline Met ID & $\begin{array}{l}\text { Baseline } \\
\text { Char. ID }\end{array}$ & Name & Condition & $\begin{array}{c}\text { A }_{\mathbf{f}} \text { of } \\
\text { Carbide }\end{array}$ & $\begin{array}{c}\text { Circularity } \\
\text { AR }\end{array}$ & $\begin{array}{c}\text { Grain } \\
\text { Size, } \mu \mathrm{m}\end{array}$ & Homogenized & $\begin{array}{c}\% \\
\text { dendrite }\end{array}$ \\
\hline DUM029 & VEVKK6-T1 & \multirow{3}{*}{$\begin{array}{c}1^{\text {st }} \text { Matthew } \\
3: 8\end{array}$} & \multirow{3}{*}{$\begin{array}{l}0.375 \text { in. no hold } \\
5 \times 5.3 \text { in. mold }\end{array}$} & 1.7 & 0.95 & 50.13 & $\mathrm{NO}$ & 32.55 \\
\hline DUM030 & VPVKK9-M1 & & & 2.2 & 0.77 & 44.64 & $\mathrm{NO}$ & 39.54 \\
\hline DUM031 & VRVKKA-B1 & & & 1.9 & 0.80 & 35.19 & $\mathrm{NO}$ & 45.17 \\
\hline DUM040 & DAVJMX-T1 & \multirow{3}{*}{$3^{\text {rd }}$ Judas 3:8 } & \multirow{3}{*}{$\begin{array}{l}0.375 \text { in. no hold } \\
5 \times 7.4 \text { in. mold }\end{array}$} & 1.1 & 0.82 & 125.00 & $\mathrm{NO}$ & 31.21 \\
\hline DUM041 & $\begin{array}{l}\text { DAVJMX- } \\
\text { M1 }\end{array}$ & & & 1.2 & 0.86 & 79.45 & $\mathrm{NO}$ & 39.40 \\
\hline DUM042 & DAVJMX-B1 & & & 1.3 & 0.88 & 66.00 & $\mathrm{NO}$ & 51.73 \\
\hline DUM043 & DC-VJLK-T1 & \multirow{3}{*}{$2^{\text {nd }}$ Judas $3: 8$} & \multirow{3}{*}{$\begin{array}{l}0.375 \text { in. 4-hour hold } \\
5 \times 7.5 \text { in. mold }\end{array}$} & 1.2 & 0.79 & 159.17 & $\mathrm{NO}$ & 23.74 \\
\hline DUM044 & $\begin{array}{c}\text { DC-VJLK- } \\
\text { M1 }\end{array}$ & & & 1.2 & 0.87 & 111.11 & $\mathrm{NO}$ & 32.15 \\
\hline DUM045 & DC-VJLK-B1 & & & 1.3 & 0.88 & 74.18 & $\mathrm{NO}$ & 50.65 \\
\hline DUM049 & YCTVLD-M1 & $2^{\text {nd }}$ Jude $3: 8$ & $\begin{array}{c}0.375 \text { in. } 4 \text {-hour hold } \\
5 \times 5.4 \text { in. mold }\end{array}$ & 1.9 & 0.86 & 55 & $\mathrm{NO}$ & 44.32 \\
\hline
\end{tabular}

\subsection{Thickness and Thermal Hold Comparison (0.200 in. vs. 0.375-in. and No Hold vs. a 4-Hour Hold)}

Figure 3.14 and Figure 3.15 show microstructures from the top and middle regions, respectively, of the casting variants. As casting thickness increases, microstructural inhomogeneity/segregation increases. Based on the microstructures (i.e., grain size and micro-segregation) the top of the cast plates took longer to cool than the bottom of the cast plates (as-marked). This was true for all castings.

The 0.200-in.-thick samples were fairly homogeneous with carbides that seem to attain an equilibrium spherical structure/shape. These carbides were dispersed uniformly across the microstructure. In comparison, the 0.375-in.-thick samples had a dendritic structure and the carbides were located in the Mo-lean regions along the grain boundaries. These carbides had a high aspect ratio and were needle-like. The 4-hour hold in case of 0.200-in.-thick samples seemed to have eliminated the inhomogeneity and increased the grain size. However, a 4-hour hold was insufficient to homogenize the 0.375-in.thick samples. Further, the effects of the 4-hour hold were more prominent at the top section 
than at the bottom section as indicated by the volume fraction of dendritic phase in the microstructure and grain size. It should be noted that no two castings of the same thickness and thermal hold time showed similar microstructures. This may be due to the difference in the mold dimensions which directly affect the cooling rate and hence the grain size and carbide morphology.

In Figure 3.16 and Figure 3.17, three dimensional (3D) images from the middle region of both a thin casting with no hold $\left(3^{\text {rd }}\right.$ Jude 0:2) and a thick casting with a 4-hour hold ( $2^{\text {nd }}$ Jude 3:8) are shown. In these images, samples were taken in the typical longitudinal cross-section, as described in Figure 2.13 (i.e., viewed in the plane of the paper), in a transverse cross-section (i.e., seen as the Z-direction into the paper) and a normal plane view, midway into the thickness of the casting. It should be noted that the microstructures were uniform in all the three directions and showed no columnar grain structure. The influence of casting conditions on the microstructure of the U-10Mo was investigated. Within each given casting condition, microstructure varied (i.e., process variability, variation in casting height, or different mold dimensions). Further, the microstructure varied from top to bottom (i.e., geometry variability). Typically, grain size was observed to be larger at the top than at the bottom, indicating faster cooling rate at the bottom than the top; the cooling rate was not measured quantitatively. All castings displayed typical macro- or micro-dendritic structure. Very little porosity was observed; however, pores that were observed were located in discreet locations between dendrites. The carbide volume fraction remained the same across all the samples and the shape/form became more spherical as the homogeneity increased. It was observed in the 0.200 -in.-thick castings with 4-hour hold (homogenous sample) that the carbides were spherical and were approximately $0.5-10 \mu \mathrm{m}$ in size and the 0.375 -in.-thick casting without any hold (least homogenous) had needle-like carbides with an aspect ratio over 5 (major axis length of 2-5 $\mu \mathrm{m})$. In Section 4 the effect of inhomogeneity and carbides on the mechanical properties and performance is discussed.

For the 0.200 -in.-thick castings with no hold, the grain size decreased from top to bottom. Some carbides were spherical and others had a large aspect ratio, indicating incomplete homogenization. This conclusion was verified by hazy Z-contrast BSE images (Figure 3.2 and Figure 3.3) and the EDS map (Figure 3.4). The grain boundaries were Mo-lean compared to the center of the grains. The Mo variation was approximately 1 to $2 \mathrm{wt} \%$. These microstructural features indicate a higher cooling rate and are representative of the inhomogeneous samples and will require further heat treatment for homogenization. For 0.200-in.-thick castings with a 4-hour hold, samples were completely homogenized and had spherical carbides. Despite the similarity in casting dimensions and hold times, the two castings investigated had varied grain sizes. Such variation is indicative of different hold temperatures/times of the casting.

The 0.375-in.-thick castings with no hold showed classic dendritic structures. Again, the grain sizes and volume fraction of dendrites decreased from top to bottom. Comparing the two samples, the grain sizes were different at the same location, indicating inconsistent casting conditions. In these cases, the dendrites were Mo-rich whereas the inter-dendritic regions were Mo-lean. The concentration varied by approximately 3 to $5 \mathrm{wt} \%$. The carbides had a high aspect ratio and were located in the Mo-lean region and were along the grain boundaries. The 0.375-in.-thick castings with a 4-hour hold had a dendritic structure and indicated lack of homogenization.

As compared to 0.200 -in.-thick castings, the 0.375-in.-thick castings showed finer grain sizes and dendritic structures. Within a given casting, at a given location, grain size and structure was observed to be similar in all directions. 


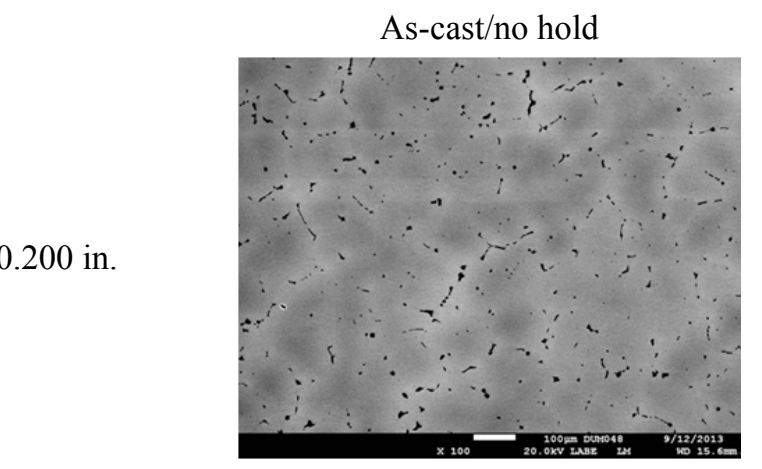

$5^{\text {th }}$ Matthew $0: 2$

$0.375 \mathrm{in}$

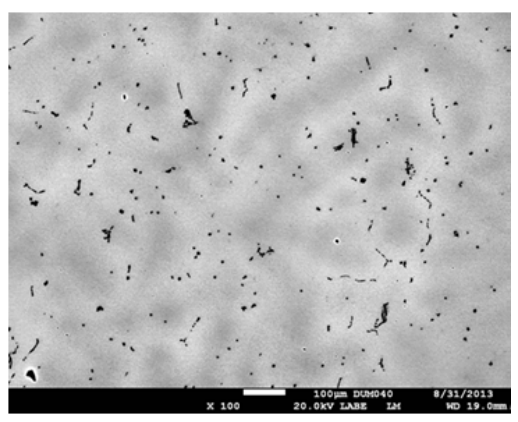

$3^{\text {rd }}$ Judas 3:8

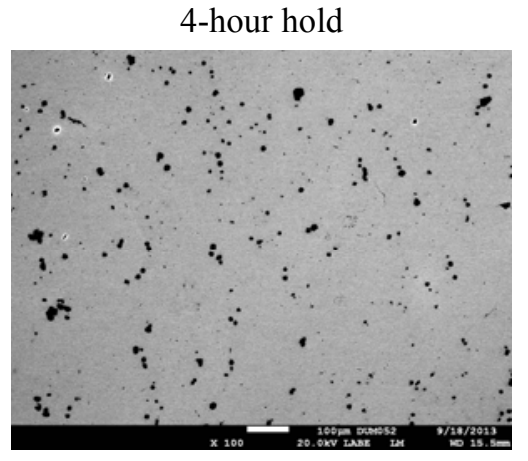

$4^{\text {th }}$ Matthew 0:2

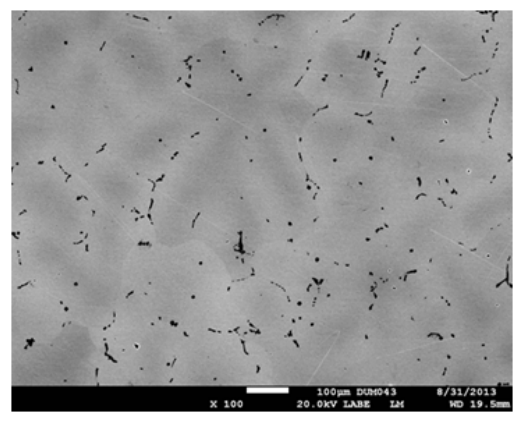

$2^{\text {nd }}$ Judas $3: 8$

Figure 3.14. SEM-BES microstructures, from the top sections of each casting, showing variation in microstructure and carbide morphology as a function of thickness and thermal hold time

$0.200 \mathrm{in}$.

As-cast/no hold

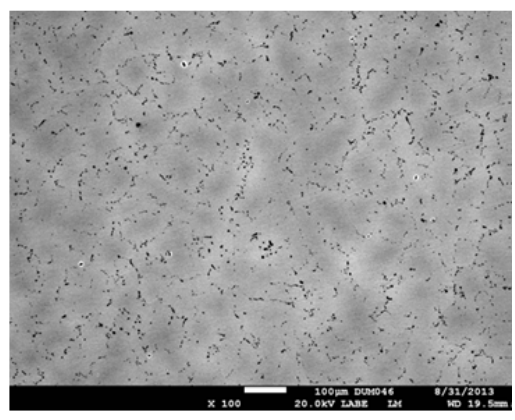

$5^{\text {th }}$ Matthew 0:2

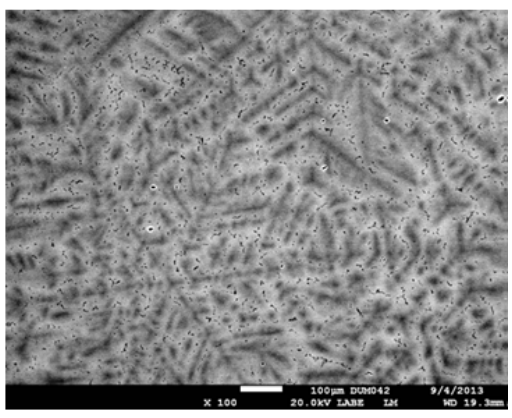

$3^{\text {rd }}$ Judas $3: 8$ 4-hour hold

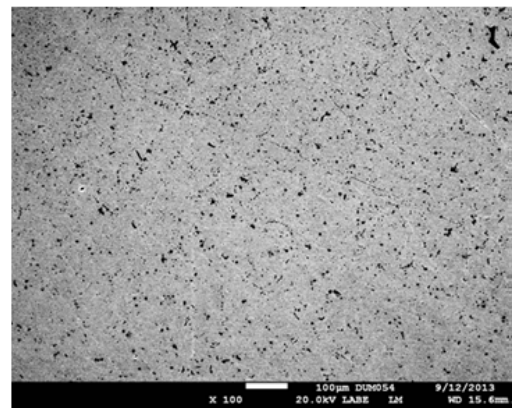

$4^{\text {th }}$ Matthew 0:2

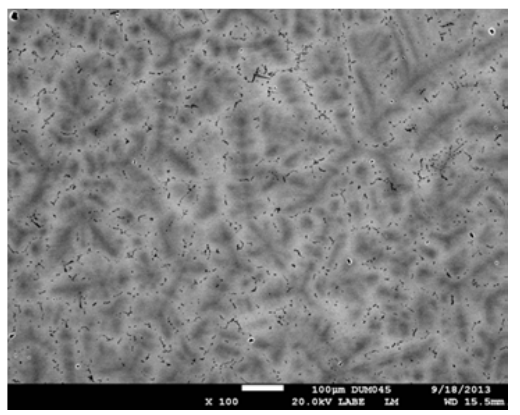

$2^{\text {nd }}$ Judas $3: 8$

Figure 3.15. Microstructures from the bottom sections as a function of thickness and hold time. 


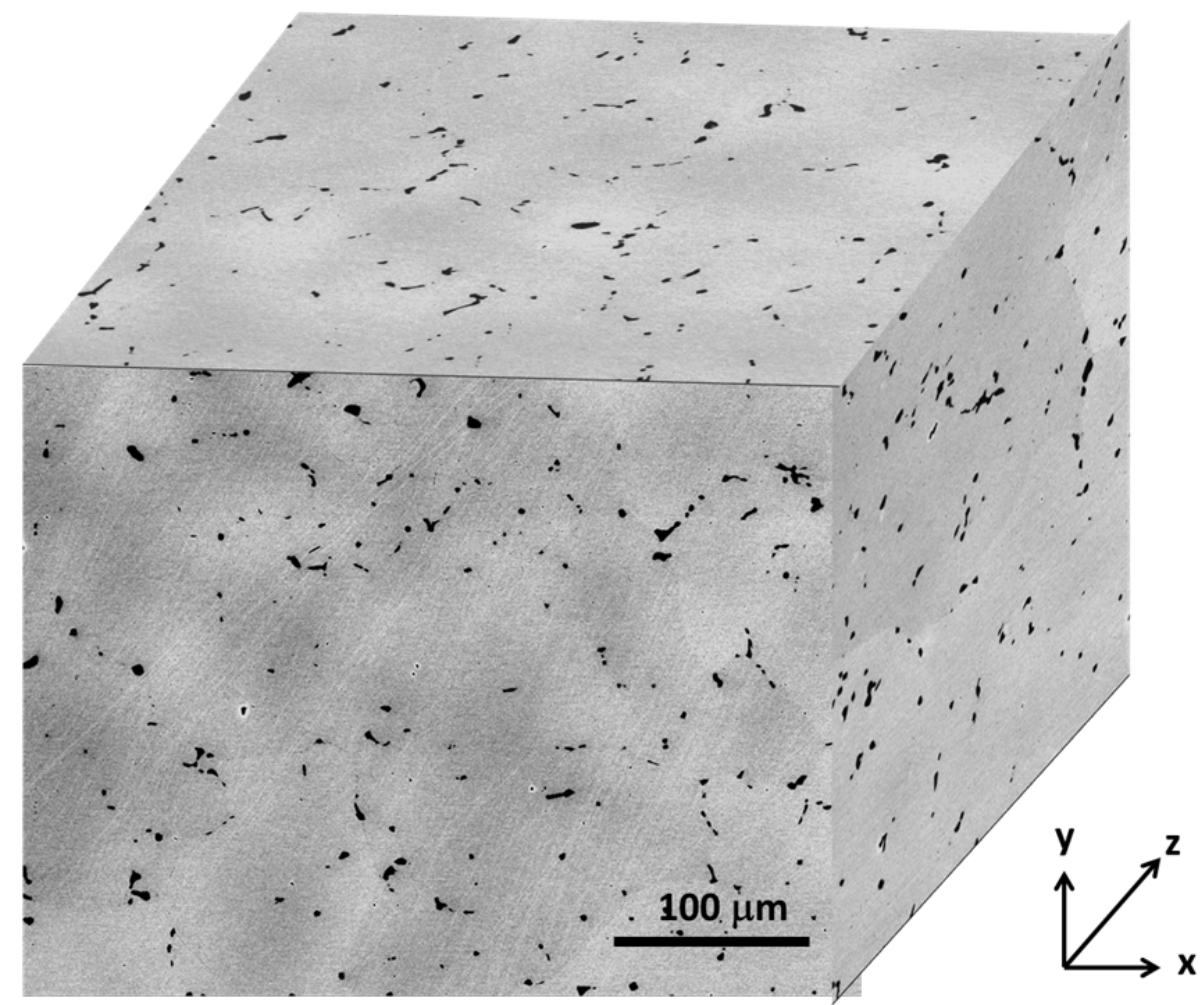

Figure 3.16. $3 \mathrm{D}$ micrograph of $3^{\text {rd }}$ Jude $0: 2$ sample ( 0.200 in. thick, no hold)

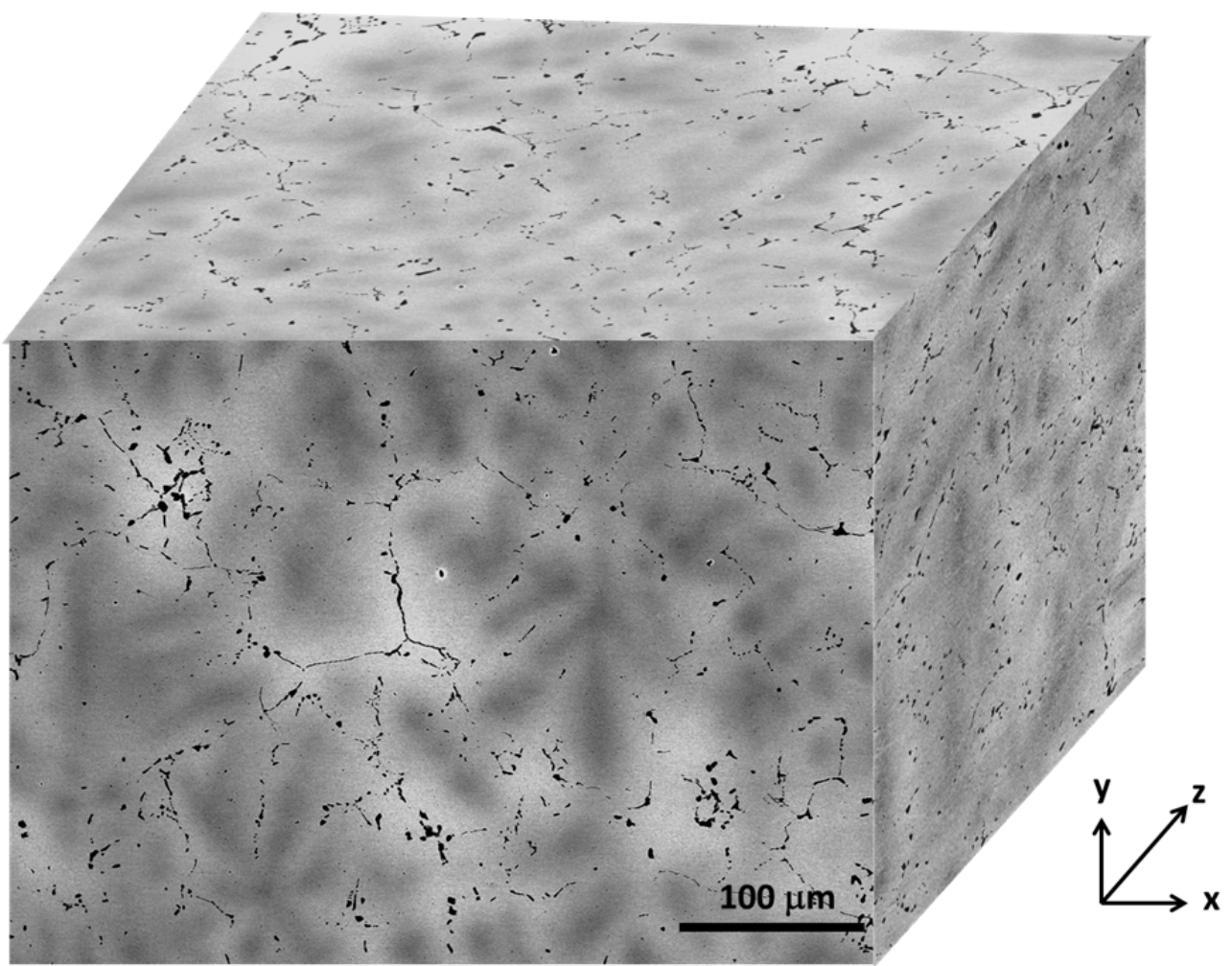

Figure 3.17. 3D micrograph of $2^{\text {nd }}$ Jude $3: 8$ sample ( 0.375 in. thick, 4-hour hold) 


\subsection{Potential Impact of Process Baseline Results}

The current work indicates that the U-10Mo castings tend to show measurable variation within, and between, samples with the same thickness. This and other investigations are currently underway at PNNL to study the effects of homogenization and carbide morphology on the microstructure and mechanical properties on U-10Mo alloys. To better understand these effects it is helpful to observe the phase equilibria (Figure 4.1). When compared to the homogenized samples, the un-homogenized samples (i.e., samples with dendritic structures) transformed rapidly into eutectoid structure and had a lower strength. Figure 4.2a shows the formation of eutectoid structure upon compression testing of U-10Mo pin casting at $500^{\circ} \mathrm{C}$, whereas Figure $4.2 \mathrm{~b}$ shows the sample homogenized at $1000^{\circ} \mathrm{C}$ for 16 hours and after compression testing at $500^{\circ} \mathrm{C}$. The homogenized sample showed no lamellar phase formation. The formation of these eutectoid/lamellar structures is not only detrimental to the mechanical properties and the processing, but may also harm the eventual in-reactor performance.
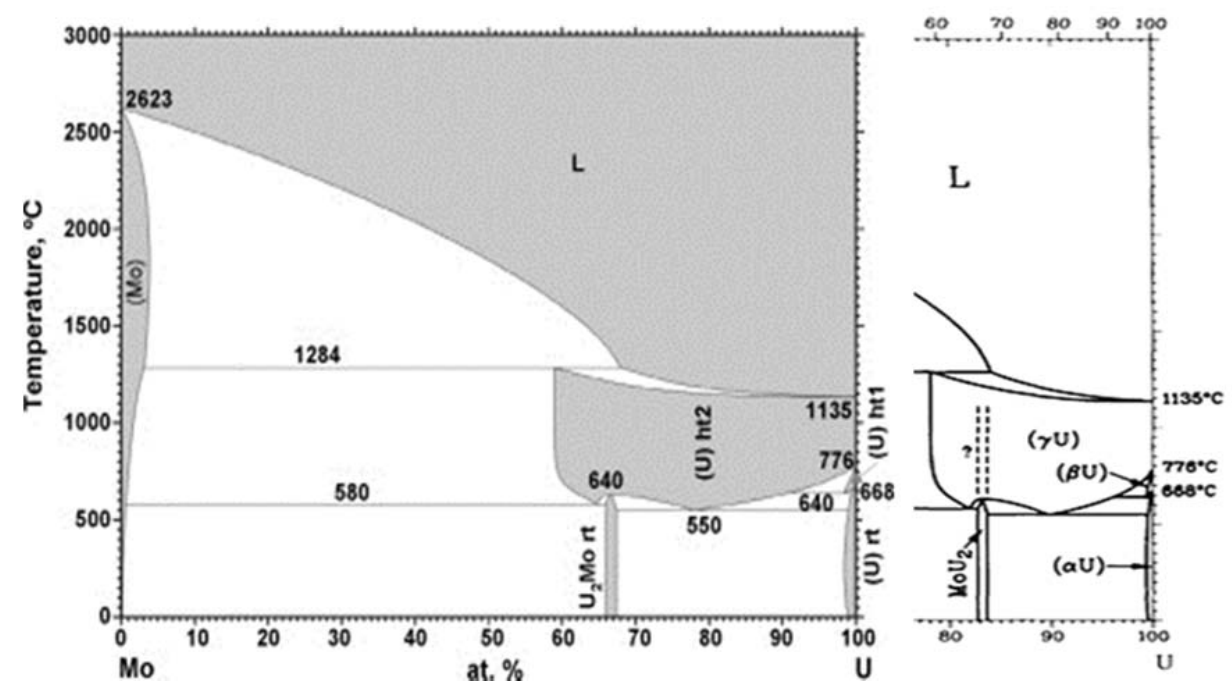

Figure 4.1. The Mo-U Binary Phase Diagram

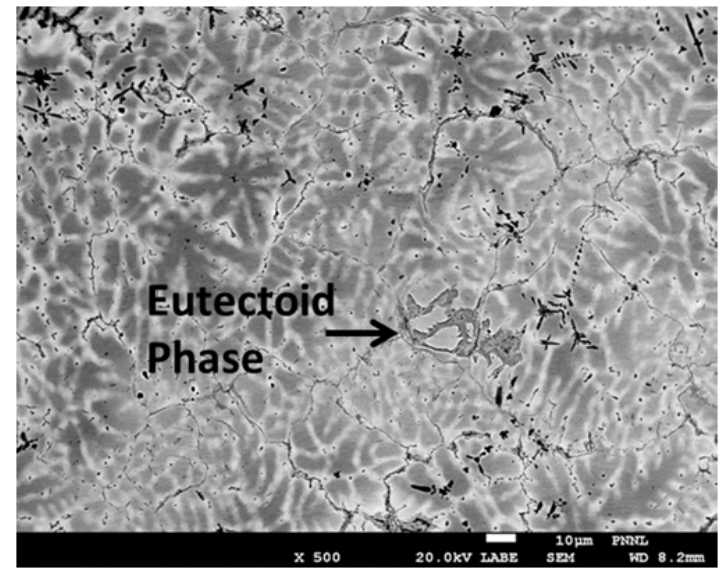

(a)

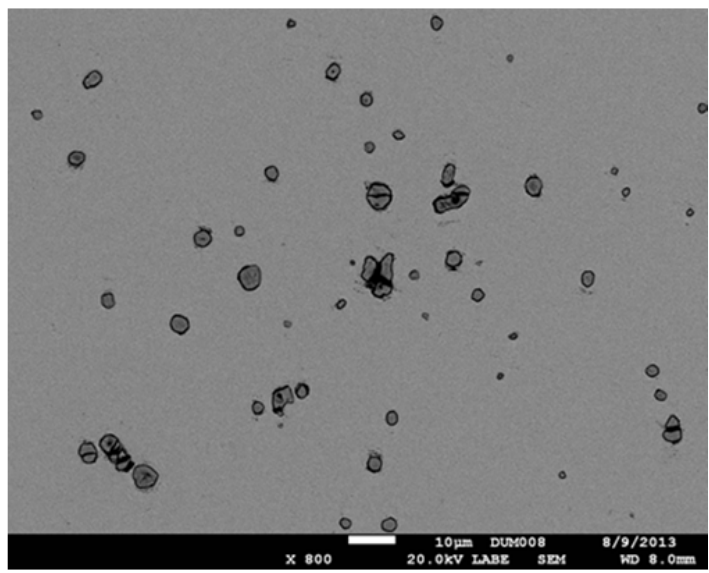

(b)

Figure 4.2. Backscattered SEM image of the sample compression tested at $500^{\circ} \mathrm{C}$ at a strain rate of $6.5 \times 10^{-4} \mathrm{~s}^{-1}$ : (a) low magnification image of the as-cast structure showing the retention of dendritic structure and formation of lamellar/eutectoid structure at the grain boundaries and (b) low magnification image of the $1000^{\circ} \mathrm{C}, 16$-hour homogenized sample. 
It should be noted that the homogenization of the sample is not the only measure of obtaining consistent processing performance/properties from U-10Mo but is also dependent on the carbide morphology and stoichiometry. Recent investigation, it has been observed that despite homogenizing the samples completely, the carbides serve as nucleation sites to form the lamellar phases. Figure 4.3a shows that homogenizing a sample at $800^{\circ} \mathrm{C}$ for 24 hours and later subjecting it to a $500^{\circ} \mathrm{C}, 8$-hour treatment resulted in over 50 percent of the structure being transformed into eutectoid/lamellar structure. In comparison, a $1000^{\circ} \mathrm{C}, 16$-hour homogenized sample, heat-treated for same time and at the temperature did not transform (Figure 4.3b). It should be noted that the only difference between the two samples was that the carbides in the $800^{\circ} \mathrm{C} / 24$-hour homogenization sample were elliptical, whereas the carbides in the $1000^{\circ} \mathrm{C} / 16$-hour samples were spherical, indicating a more stable carbide phase or morphology. Figure 4.3 is the effect of a $500^{\circ} \mathrm{C}, 8$-hour heat treatment on the as-cast sample. It was observed that the sample had fewer dendrites than the $800^{\circ} \mathrm{C} / 24$-hour homogenized sample.

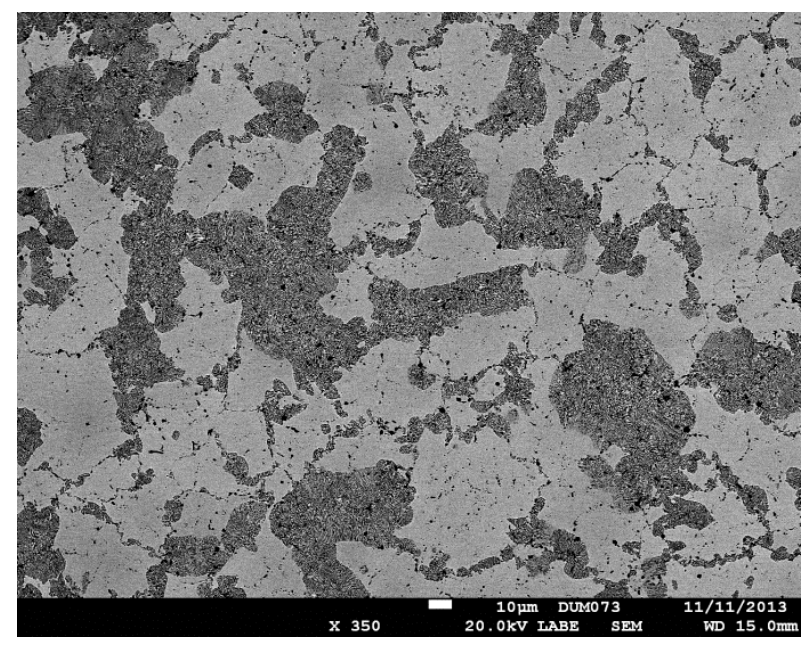

(a)

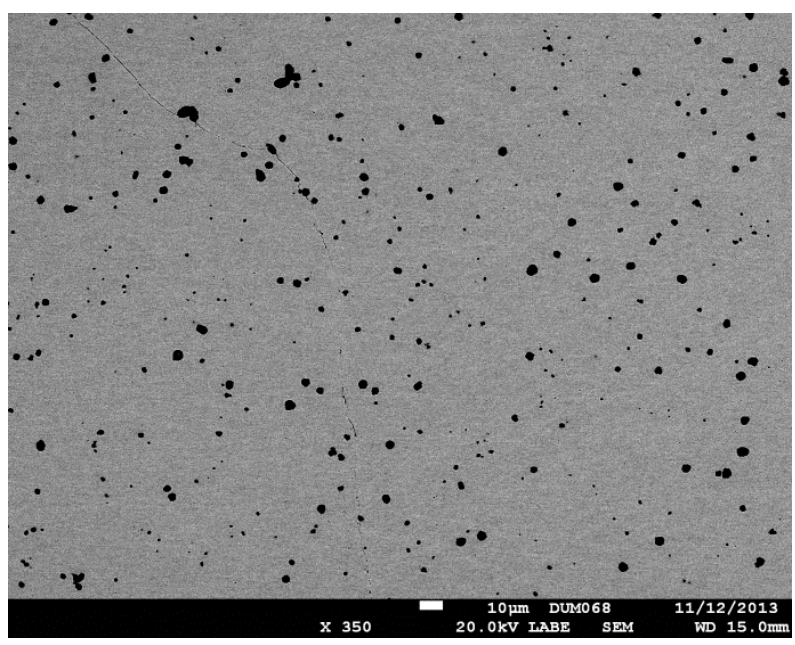

(b)

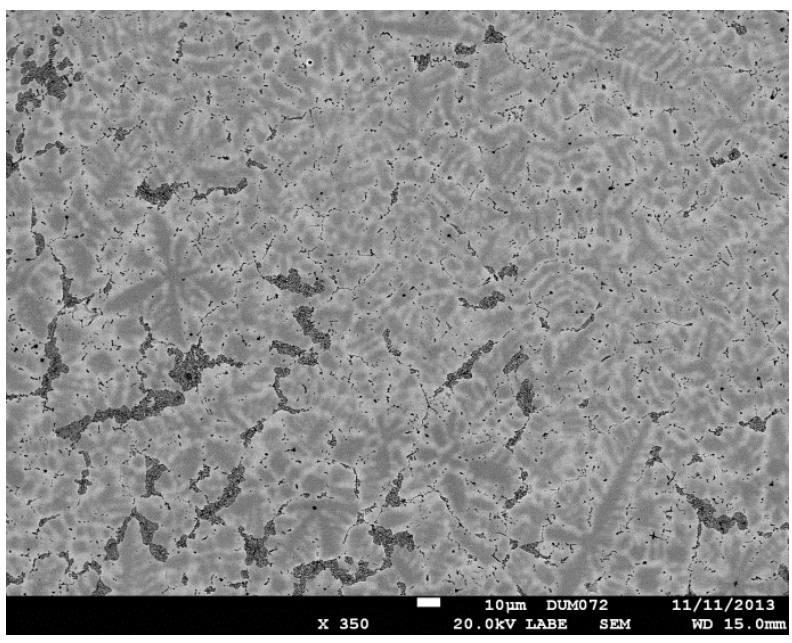

(c)

Figure 4.3. BSE-SEM images showing the effect of heat treating U-10Mo samples (a) homogenized at $800^{\circ} \mathrm{C}$ for 24 hours, (b) homogenized at $1000^{\circ} \mathrm{C}$ for 16 hours and (c) as-cast. Initial condition/heat treatments were followed by $500^{\circ} \mathrm{C}$, 8-hour treatment. 


\subsection{Conclusions and Recommendations}

A process baseline characterization study was conducted at PNNL on U-10Mo cast plates produced at Y-12. This study has been useful to characterize the current casting process and system design used at Y-12 to produce the U-10Mo fuel plates. In addition, this work should help identify potential unintended changes to composition and microstructure should the process is changed or the furnace is redesigned. Based on the specific castings evaluated, the following conclusions and recommendations are provided.

\subsection{Conclusions}

1. No gross porosity was observed. A small fraction (less than 2 percent) of porosity of less than $25 \mu \mathrm{m}$ micron appeared primarily in discreet locations between dendrites.

2. No coarse carbides (i.e., greater than $20 \mu \mathrm{m}$ micron) were observed.

3. No gross segregation was observed.

4. On a microstructural scale, inhomogeneity was observed in three forms: Mo segregation, grain size, and carbide size and distribution.

a. The Mo segregation was less on the top of the castings, possibly due to hot-topping or proximity to the hot furnace.

b. The grain size was largest for the 0.200 -in. castings with a 4-hour thermal hold and smallest for the 0.375 -in. castings with no hold. In all samples, the top of the castings had larger grain size than the bottom of the castings.

c. The carbides were finer and less evenly distributed in the bottom of the castings and were predominately at grain boundaries. The carbides were coarser and more evenly distributed on the top of the castings and could be found both within the grain and at the boundaries.

d. Inhomogeneity from top to bottom was observed in the castings and was likely due to mold temperature gradients and the coring tendency of U-Mo.

5. The grains were, in general, equiaxed, with decreasing grain size away from the top. Columnar grains were not observed, but dendritic microstructure was commonly observed in the 0.375 -in.-thick samples.

6. The 4-hour hold did not homogenize the Mo in the 0.375-in.-thick castings but appeared to homogenize the Mo in the 0.200 -in.-thick castings, likely due to the shorter diffusion distance associated with the smaller dendrite size.

7. Castings produced under similar conditions had different grain size profiles, suggesting some degree of process variation.

\subsection{Recommendations}

1. It should be verified that the U-10Mo does not transform after homogenization. In similar inhomogeneous U-10Mo microstructures, transformation of the U-Mo to alpha $\mathrm{U}$ and $\mathrm{U}_{2} \mathrm{Mo}$ has been observed. Thus, care should be taken to ensure that the in-mold homogenization does not lead to a transformed structure. It is not clear if transformation is a grain size or carbide effect; however, it 
appears that a carbide/grain size effect exists that should be quantified. Homogenization temperatures have not been quantified, but it appears that a minimum of $1000^{\circ} \mathrm{C}$ may be required. A robust homogenization process must be established to prevent transformation.

2. Disparity in grain size observed from the top of a casting (large grain size) to the bottom (fine grain size) and run-to-run, suggests tighter control of the thermal gradient is required. Therefore, it is recommended that proper mold temperature gradient be established through enhanced process control and/or improved mold design. Furthermore, the gradient in top to bottom microstructure of the castings may be alleviated by homogenization, but the time and possibly temperature to homogenize may be influenced by the gradient in the casting temperature. 


\subsection{References}

Burkes DE, T Hartmann, R Prabhakaran, and J-F Jue. 2009. "Microstructural Characteristics of DU-X Mo Alloys with $\mathrm{x}=7$ - $12 \mathrm{Wt} \%$," Journal of Alloys and Compounds, 479(1-2):140-147.

doi:http://dx.doi.org/10.1016/j.jallcom.2008.12.063.

Burkes DE, CA Papesch, AP Maddison, T Hartmann, and FJ Rice. 2010a. "Thermo-Physical Properties of DU-10 Wt\% Mo Alloys," Journal of Nuclear Materials, 403(1-3):160-166.

doi:http://dx.doi.org/10.1016/j.jnucmat.2010.06.018.

Burkes DE, R Prabhakaran, T Hartmann, J-F Jue, and FJ Rice. 2010b. "Properties of DU-10 Wt\% Mo Alloys Subjected to Various Post-Rolling Heat Treatments," Nuclear Engineering and Design, 240(6):1332-1339. doi:http://dx.doi.org/10.1016/j.nucengdes.2010.02.008.

Snelgrove JL, GL Hofman, MK Meyer, CL Trybus, and TC Wiencek. 1997. "Development of VeryHigh-Density Low-Enriched-Uranium Fuels," Nuclear Engineering and Design, 178(1):119-126. doi:http://dx.doi.org/10.1016/S0029-5493(97)00217-3.

Clark CR, JF Jue, GA Moore, NP Hallinan, and BH Park. 2006. "Update on Monolithic Fuel Fabrication Methods," THE 2006 RERTR INTERNATIONAL MEETING, Cape Town, South Africa, Vol.

Mcgeary RK. 1955. Development and Properties of Uranium-Base Alloys Resistant to Corrosion in High-Temperature Water, USAEC Report WAPD-127 Part I.

Dombrowski DE. 2012. Overview of LANL Progress in Process Development, Advanced Characterization Methods and Prototype Fabrication. In Proceedings of RERTR 2012, 34th INTERNATIONAL MEETING ON REDUCED ENRICHMENT FOR RESEARCH AND TEST REACTORS, Warsaw, Poland.

Joshi VV, EA Nyberg, CA Lavender, D Paxton, H Garmestani, and DE Burkes. 2013.

"Thermomechanical Process Optimization of U-10wt\% Mo - Part 1: High-Temperature Compressive Properties and Microstructure," Journal of Nuclear Materials, (Available Online Published on $14^{\text {th }}$ Nov, 2013). doi:http://dx.doi.org/10.1016/j.jnucmat.2013.10.065.

Sinha VP, PV Hegde, GJ Prasad, GK Dey, and HS Kamath. 2010a. "Effect of Molybdenum Addition on Metastability of Cubic $\gamma$-Uranium," Journal of Alloys and Compounds, 491(1-2):753-760.

doi:http://dx.doi.org/10.1016/j.jallcom.2009.11.060.

Sinha VP, PV Hegde, GJ Prasad, GK Dey, and HS Kamath. 2010b. "Phase Transformation of Metastable Cubic $\gamma$-Phase in U-Mo Alloys," Journal of Alloys and Compounds, 506(1):253-262. doi:http://dx.doi.org/10.1016/j.jallcom.2010.06.187.

Sinha VP, GJ Prasad, PV Hegde, R Keswani, CB Basak, S Pal, and GP Mishra. 2009. "Development, Preparation and Characterization of Uranium Molybdenum Alloys for Dispersion Fuel Application," Journal of Alloys and Compounds, 473(1-2):238-244. doi:http://dx.doi.org/10.1016/j.jallcom.2008.05.061. 



\section{Appendix A}

Table of Samples Received from Y-12

\begin{tabular}{|c|c|c|c|}
\hline Met ID & Baseline Char. ID & Name & Condition \\
\hline DUM026 & YN-TVLD-Top & \multirow{5}{*}{$3^{\text {rd }}$ Jude $0: 2$} & \multirow{5}{*}{$\begin{array}{l}0.200 \text {-in./no hold } \\
8 \times 9.1 \text { in. casting }\end{array}$} \\
\hline DUM027 & YN-TVLD-Middle LT & & \\
\hline DUM028 & YN-TVLD-Bottom & & \\
\hline DUM051 & YN-TVLD Mid CT & & \\
\hline DUM056 & YN-TVLD Long-Plane & & \\
\hline DUM029 & VEVKK6-T1 & \multirow{3}{*}{$1^{\text {st }}$ Matthew 3:8 } & \multirow{3}{*}{$\begin{array}{l}0.375 \text {-in./no hold } \\
5 \text { x } 5.3 \text { in. casting }\end{array}$} \\
\hline DUM030 & VPVKK9-M1 & & \\
\hline DUM031 & VRVKKA-B1 & & \\
\hline DUM037 & YH-TVLD-Top & \multirow{3}{*}{$4^{\text {th }}$ Jude $0: 2$} & \multirow{3}{*}{$\begin{array}{l}0.200 \text {-in./4-hour hold } \\
8 \times 8.5 \text { in. casting }\end{array}$} \\
\hline DUM038 & YH-TVLD-Middle & & \\
\hline DUM039 & YH-TVLD-Bottom & & \\
\hline DUM040 & DA-VJMX-Top & \multirow{3}{*}{$3^{\text {rd }}$ Judas $3: 8$} & \multirow{3}{*}{$\begin{array}{l}0.375 \text {-in./no hold } \\
5 \times 7.4 \text { in. casting }\end{array}$} \\
\hline DUM041 & DA-VJMX-Middle & & \\
\hline DUM042 & DA-VJMX-Bottom & & \\
\hline DUM043 & DC-VJLK-Top & \multirow{3}{*}{$2^{\text {nd }}$ Judas 3:8 } & \multirow{3}{*}{$\begin{array}{l}0.375 \text {-in./4-hour hold } \\
5 \times 7.5 \text { in. casting }\end{array}$} \\
\hline DUM044 & DC-VJLK-Middle & & \\
\hline DUM045 & DC-VJLK-Bottom & & \\
\hline DUM046 & YN-TW8W-Top & \multirow{3}{*}{$5^{\text {th }}$ Matthew $0: 2$} & \multirow{3}{*}{$\begin{array}{l}0.200 \text {-in./no hold } \\
8 \times 8.5 \text { in. casting }\end{array}$} \\
\hline DUM047 & YN-TW8W-Middle & & \\
\hline DUM048 & YN-TW8W-Bottom & & \\
\hline DUM049 & YC-TVLD-Middle LT & \multirow{3}{*}{$2^{\text {nd }}$ Jude $3: 8$} & \multirow{3}{*}{$\begin{array}{l}0.375 \text {-in./4-hour hold } \\
5 \times 5.4 \text { in. casting }\end{array}$} \\
\hline DUM050 & YC-TVLD-Mid CT & & \\
\hline DUM055 & YC-TVLD Long-plane & & \\
\hline DUM052 & YH-TW8W Top & \multirow{3}{*}{$4^{\text {th }}$ Matthew $0: 2$} & \multirow{3}{*}{$\begin{array}{l}0.200 \text {-in./4-hour hold } \\
8 \times 9.4 \text { in. casting }\end{array}$} \\
\hline DUM053 & YH-TW8W Middle & & \\
\hline DUM054 & YH-TW8W Bottom & & \\
\hline
\end{tabular}





\section{Distribution}

No. of

Copies

1 Department of Energy National Nuclear Security Administration

Global Threat Reduction Initiative

1000 Independence Ave.

Washington, DC 20002

Mr. Christopher Landers

Dr. Natraj Iyer

1 Idaho National Laboratory

P.O. Box 1625

Idaho Falls, ID 83415

Mr. Kenneth Rosenberg

Dr. Mitchell Meyer

1 Argonne National Laboratory

$9700 \mathrm{~S}$ Cass Ave.

Argonne, IL 60439

Dr. John Stevens
No. of

\section{Copies}

$4 \quad$ Local Distribution

Pacific Northwest National Laboratory

Eric Nyberg

K2-03

Vineet Joshi

K2-03

Curt Lavender

K2-03

Dan Edwards

Douglas Burkes

$\mathrm{J} 4-55$

Dean Paxton
K8-34

K2-03 


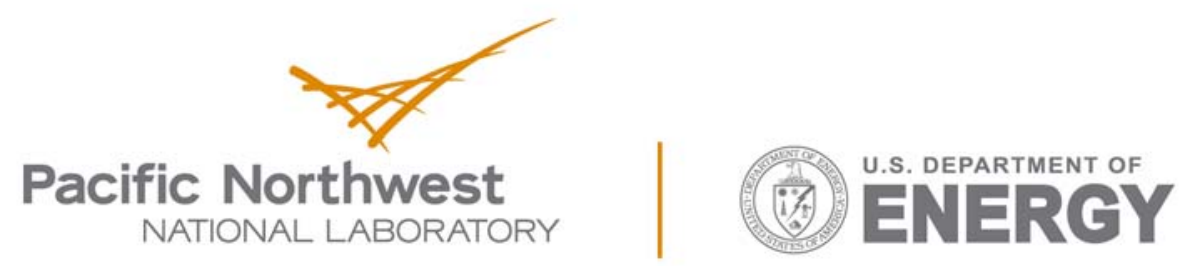

Proudly Operated by Battelle Since 1965

902 Battelle Boulevard

P.O. Box 999

Richland, WA 99352

1-888-375-PNNL (7665)

www.pnnl.gov 